REVISTA DE DERECHO UNED, NÚM. 23, 2018

\title{
LA REFORMA DE LA CONSTITUCIÓN DE 1978: RAZONES DE SU CONVENIENCIA Y ALGUNA SUSPICACIA SOBRE SU VIABILIDAD
}

THE REFORM OF THE CONSTITUTION OF 1978: REASONS FOR THE CONVENIENCE AND SUSPICIONS ABOUT THE VIABILITY

\author{
Premio de Artículos Jurídicos «García Goyena» \\ XVII Edición \\ Seleccionado para publicación
}

Germán M. TERUEl LoZANO

Profesor de Derecho Constitucional. Universidad de Murcia

Resumen: Este trabajo tiene por objeto estudiar aquellas «exigencias políticas» que justifican la conveniencia de reformar la Constitución de 1978 y su perímetro. Al mismo tiempo, se reconocerán aquellos factores políticos que cuestionan la viabilidad de este proyecto. Por último, se advertirán los riesgos aparejados a la falta de reforma constitucional y se propondrá una reforma «serena» y "prudente» como antídoto frente a su envejecimiento y, especialmente, como ocasión para forjar una necesaria concordia política que refuerce la función de integración de la Constitución ante la actual crisis.

Palabras clave: reforma constitucional, Constitución española, democracia.

Abstract: This paper aims to study those "political demands" that justify the convenience of reforming the Constitution of 1978 and to analyse the perimeter of the reforms. At the same time, it rec- 
ognizes political factors that question the viability of this project. Finally, the paper warns of the risks associated with the lack of constitutional reform. A «sober» and «wise» reform will be presented as an antidote to the aging of the Constitution and, especially, as an occasion to forge the political concord which it is necessary so as to reinforce the role of integration of the Constitution besides the current crisis.

Keywords: constitutional reform, Spanish Constitution, democracy.

Sumario: I. Introducción: La reforma constitucional como reto jurídico-político para la sociedad española del siglo XXI.--II. A modo de antecedente: intentos frustrados y falseados de reformar la Constitución de 1978.- - III. Razones de la conveniencia, aunque no urgente necesidad, de reformar la Constitución de 1978.--IV. "Momento reformista», que no "constituyente».-V. El perímetro de la reforma constitucional posible.-VI. Dudas sobre la viabilidad de la reforma constitucional reconducidas a una suspicacia final: la actitud (quizá aptitud) política.-VII. A modo de cierre: la reforma constitucional, si es prudente y serena, como antídoto frente al envejecimiento de la Constitución de 1978.--VIII. Bibliografía.

\section{INTRODUCCIÓN: LA REFORMA CONSTITUCIONAL COMO RETO JURÍDICO-POLÍTICO PARA LA SOCIEDAD ESPAÑOLA DEL SIGLO XXI}

La Constitución de 1978 puede ser reconocida como la gran obra jurídica española del siglo xx. La misma ha consolidado un marco jurídico eficaz que ha garantizado nuestra convivencia democrática pacífica durante cuatro décadas, permitiéndonos disfrutar de un efectivo pluralismo político, de un amplio reconocimiento de unos derechos fundamentales y de una notable descentralización política. Se ha tratado del período democrático más largo de nuestra Historia $^{1}$. Es por ello que no parece exagerado ver en la actual Constitución española un «new beginning», como ha expresado el profesor Muñoz Machado².

${ }^{1}$ Como expresa PÉREZ ROYO, J., La reforma constitucional inviable, Catarata, Madrid, 2015, p. 27, «el impulso constitucional de "la Transición" ha sido, sin duda, desde la perspectiva democrática, el impulso más fecundo de nuestra historia».

2 MUÑOZ MACHADO, S., Vieja y nueva Constitución, Crítica, Barcelona, 2016, p. 8 . 
Algo que se ha podido lograr gracias a que la misma fue una "Constitución de compromiso, de "consenso" " ${ }^{3}$. Como explica Rubio Llorente «todas las fuerzas políticas pusieron la necesidad de obrar en común por encima de sus propias preferencias y lograron alumbrar un texto consensuado, excepcional en la agitada historia política española» ${ }^{4}$. Una rara avis en el constitucionalismo español ${ }^{5}$. Parecía que se lograba acabar con el «maleficio» de aprobar constituciones «mediante "trágalas", por una España contra la otra $»^{6}$. Lo cual ha llevado también, como contraparte, a una cierta «sacralización» ${ }^{7}$ de la Constitución. De lo que se ha podido deducir algo bueno, y es que, con los años, se ha creado un cierto patriotismo constitucional y una cierta cultura de respeto a la misma ${ }^{8}$; pero, al mismo tiempo, ha generado algún temor a romper su hasta cierto punto virginal ${ }^{9}$ condición para adaptarla a los nuevos tiempos.

3 PÉREZ ROYO, J., La reforma de la Constitución, Congreso de los Diputados, Madrid, 1987, p. 123.

${ }^{4}$ RUBIO LLORENTE, F., «Defectos de forma», Revista Española de Derecho Constitucional, n. 100, 2014, p. 135.

${ }^{5}$ Cfr. PÉREZ ROYO, J., La reforma de la Constitución, ob. cit., p. 123, quien se refiere también a lo singular de la Constitución española en la historia constitucional.

${ }^{6}$ DE CARRERAS SERRA, F., "Conveniencia y necesidad de una reforma constitucional», Claves de razón práctica, n. 241, 2015, p. 40. Sobre las diferentes maneras de incumplir, cambiar o abrogar la Constitución en la práctica española, vid. MUÑOZ MACHADO, S., Vieja..., ob. cit., pp. 76 y ss. Y más en general en relación con el poder de reforma en la historia constitucional española, cfr. RUBIO LLORENTE, F., «Rigidez y apertura en la Constitución» en AA.VV., La reforma constitucional: ¿hacia un nuevo pacto constituyente?, CEPC, Madrid, 2009, pp. 17-40.

7 A este proceso de sacralización se refiere LÓPEZ AGUILAR, J.F., «De la Constitución «irreformable» a la reforma constitucional «exprés»», Teoría y Realidad Constitucional, n. 29, 2012, p. 201. También GARCÍA ROCA, J., «De la revisión de las constituciones: constituciones nuevas y viejas», Teoría y Realidad Constitucional, n. 40, 2017, p. 208, señala el riesgo de sacralizar la Constitución.

${ }^{8}$ En un momento en el que España ha sufrido la dura embestida de un nacionalismo secesionista que ha tratado abiertamente de romper con la Constitución apoyado por un amplio sector de la población en Cataluña, hay que afirmar con cautela la consolidación de una cultura constitucional en nuestro país. Es verdad que, por el contrario, las manifestaciones vividas en Cataluña en defensa de la Constitución o la exhibición de banderas de España por todo el territorio nacional en algunos casos pueden ser expresión de un nacionalismo españolista, pero también creo que en muchos otros son signo de un sano patriotismo constitucional.

${ }^{9}$ Las dos reformas constitucionales que se han producido de la Constitución española de 1978 fueron tan mínimas que por ello me permita reconocer, aunque resulta paradójico, la condición prácticamente "virginal» de nuestra Constitución. 
Se presenta así la cuestión de la reforma constitucional ${ }^{10}$ : la «asignatura pendiente» de nuestra sociedad ${ }^{11}$.

Aprobar esta asignatura representa, a mi juicio, uno de los mayores desafíos jurídico-políticos del siglo XXI en España ${ }^{12}$ : ¿lograremos salvar las dudas que se presentan en cuanto a la oportunidad de la reforma para actualizar nuestra Norma Fundamental a la realidad política y social y a las exigencias jurídicas de este siglo? ¿Seremos capaces de superar nuestro «bárbaro sistema de inestabilidad constitucional» por el que nos habíamos habituado a «edificar una Constitución nueva sobre las ruinas de la anterior», en definitiva a sustituir abruptamente una constitución por otra en puesto de reformarlas con serenidad ${ }^{13}$ Lógicamente, este trabajo no puede pretender adivinar el futuro, por lo que su propósito es mucho más modesto. A lo largo del mismo se tratarán de aportar razones sobre la conveniencia jurídica de afrontar la reforma de la Constitución de 1978, perfilando los nudos gordianos de la misma y atisbando las vías para andar este camino, al tiempo que se reconocerán aquellos factores que pueden cuestionar la viabilidad de la misma. Y, para ello, propongo

10 Sobre la reforma constitucional en general, véanse, entre otros: DE VEGA, P., La reforma constitucional y la problemática del poder constituyente, Tecnos, Madrid, 1985; PÉREZ ROYO, J., La reforma de la Constitución, ob. cit.; GARCÍA-ATANCE, M.V., Reforma y permanencia constitucional, CEPC, Madrid, 2002; VERA SANTOS, J.M., La reforma constitucional en España, La Ley, Madrid, 2007; RUBIO LLORENTE, F., «Rigidez...», ob. cit.

${ }_{11}$ Tal y como advierte PÉREZ ROYO, J., La reforma constitucional inviable, ob. cit., pp. 27-28, a través de los procedimientos de reforma «la sociedad española debería de ser capaz de resolver políticamente, pero de manera jurídicamente ordenada, cualquier problema con el que tuviera que enfrentarse. Es lo que ocurre en los demás países europeos occidentales (...). Periódicamente hacen uso de la reforma constitucional y renuevan de esta manera la legitimidad constituyente originaria». Sin embargo, «En España no es así. La reforma de la Constitución es la última asignatura constitucional de la que la sociedad española tiene que examinarse. Porque todavía no se ha examinado", las dos reformas constitucionales no han sido propiamente reformas constitucionales españolas.

${ }_{12}$ Comparto con RUBIO LLORENTE, F., "Rigidez y rigor mortis», Claves de razón práctica, n. 241, 2015, p. 17, que «[u]na Constitución de la que la mayoría puede disponer a su arbitrio, es una Constitución muerta; pero también se puede dar por muerta una Constitución que no puede ser reformada, o solo en lo trivial. La rigidez se convierte en rigor mortis».

${ }^{13}$ Las citas son de GARCÍA ROCA, J. (ed.), Pautas para una reforma constitucional, Aranzadi, Navarra, 2014, p. 18, donde califica ésta como «la maldición del constitucionalismo español». PÉREZ ROYO, J., La reforma constitucional inviable, ob. cit., p. 31-32, por su parte, responde a esta pregunta con pesimismo: «Parece, sin embargo, que no hemos sido capaces de esquivar esa maldición de que las constituciones no se reforman sino que se desmoronan y acaban teniendo que ser sustituidas por otra». 
empezar recordando algunos intentos frustrados y falseados de reformar nuestra actual Constitución.

\section{A MODO DE ANTECEDENTE: INTENTOS FRUSTRADOS Y FALSEADOS DE REFORMAR LA CONSTITUCIÓN DE 1978}

La reforma de la Constitución de 1978 se ha convertido en un debate recurrente en nuestro país, tanto a nivel jurídico como político, caracterizado por notables contribuciones que, sin embargo, han tenido corto recorrido práctico, y por peligrosos intentos de falseamiento ${ }^{14}$ ante la frustración por la falta de consecución de la misma. Hoy por hoy, como se señalaba anteriormente, la Constitución española permanece prácticamente virgen. Así las cosas, acerquémonos aunque sea someramente a lo sucedido en estos años de vida constitucional.

Tras una primera década donde la cuestión de la reforma constitucional sólo se planteó en alguna literatura general sobre este instituto de garantía ${ }^{15}$, en los noventa por primera vez se abrió un debate sobre la posibilidad de introducir reformas en la Constitución española ${ }^{16}$. Influyeron, entre otros factores, la leve reforma de la Constitución efectuada en el año 1992 para añadir el inciso "y pasivo» en el artículo 13.2 que regula el derecho al sufragio de los extranjeros en elecciones municipales, como exigencia derivada del Tratado de Maastricht ${ }^{17}$; y la constitución en el Senado de una Comisión espe-

${ }_{14}$ MUÑOZ MACHADO, S., Vieja..., ob. cit., p. 142, expone la diferencia acuñada por la doctrina francesa entre "faussement de la Constitution" y "fraude à la Constitution». La primera supondría dar un sentido a las normas constitucionales distinto al que realmente tienen; y la segunda implicaría la creación de un nuevo orden constitucional pero sin romper con la legalidad establecida.

${ }^{15}$ En particular, cfr. DE VEGA, P., ob. cit., y PÉREZ ROYO, J., La reforma de la Constitución, ob. cit.

${ }_{16}$ Véase la explicación que se realiza en DÍAZ REVORIO, F.J., «Perspectivas de la reforma de la Constitución española», Parlamento y constitución, n. 8, 2004, pp. 11-37; LÓPEZ AGUILAR, J.F., ob. cit.; y TORRES DEL MORAL, A., «Estado autonómico...», ob. cit, pp. 49 y ss.

17 La DTC 1/1992, de 1 de julio, declaró que el Tratado de la Unión Europea resultaba contrario a la Constitución y, por ende, ésta debía reformarse para poder suscribir el mismo. La iniciativa de reforma fue presentada conjuntamente el 7 de julio de ese mismo año por los Grupos Parlamentarios Socialista, Popular, Catalán (Convergència y Unió), Izquierda Unida-Iniciativa per Catalunya, CDS, Vasco (PNV) y Mixto. Se tramitó al amparo del artículo $167 \mathrm{CE}$ y el Congreso decidió su adopción en lectura única. Fue adoptada por 332 votos a favor (la totalidad de los emitidos). En el Senado el texto fue aprobado sin enmiendas. Finalmente, no fue solicitado referéndum por lo que el texto definitivo de la reforma fue publicado el 28 de agosto de 1992, tras haber recibido la sanción y promulgación regia el día anterior. 
cial para el estudio de la reforma constitucional de esa Cámara en 1996. Sin embargo, al final esta cuestión no tuvo mayor recorrido y durante el período 1996-2004 bajo el Gobierno de José María Aznar la idea de la reforma constitucional quedó congelada ${ }^{18}$. Ello a pesar de las presiones que empezaban a surgir, especialmente con el Plan Ibarretxe que fue anunciado por el Lehendakari vasco en septiembre de $2001^{19}$.

En la VIII Legislatura (2004-2008), con el gobierno socialista de José Luis Rodríguez Zapatero, se recuperaba la idea de la reforma constitucional. En la sesión solemne de apertura de aquellas Cortes Generales su ahora tristemente desaparecido Presidente, Manuel Marín, comenzaba destacando que "se avecina[ba] una Legislatura de grandes momentos constitucionales ${ }^{20}$. Poco tiempo después, en marzo de 2005, por acuerdo del Consejo de Ministros se solicitó al Consejo de Estado un informe sobre la reforma constitucional, que fue aprobado en febrero de $2006^{21}$. También a nivel doctrinal empezaron a surgir interesantes trabajos ${ }^{22}$. Sin embargo, este impulso no se tradujo en una propuesta concreta de reforma constitucional y la misma quedó encallada en una legislatura que se caracterizó especialmente por su crispación ${ }^{23}$. De forma paralela sí que se desarro-

${ }^{18}$ LÓPEZ AGUILAR, J.F., ob. cit., p. 201, se refiere a cómo en estos años alcanza su "punto álgido» esta «involución hiperconservadora a conservacionista de la Constitución».

${ }_{19}$ Este proyecto de reforma del Estatuto de autonomía del País Vasco, claramente superador de los límites constitucionales, fue presentado en octubre de 2003 al Parlamento Vasco, que lo aprobó en diciembre de 2004. En febrero de 2005 el Pleno del Congreso de los Diputados lo rechazó por 313 votos en contra (PSOE, PP, IU, Coalición Canaria, y Chunta Aragonesista).

${ }^{20}$ Intervención del Sr. Presidente del Congreso de los Diputados, Marín González, en la solemne sesión conjunta del Congreso de los Diputados y del Senado celebrada el 22 de abril de 2004, con motivo de la apertura de la VIII Legislatura Constitucional.

${ }^{21}$ CONSEJO DE ESTADO: Informe sobre modificaciones de la Constitución española, 16 de febrero de 2006. Este trabajo se limitó a estudiar los siguientes puntos: $\left.1 .^{\circ}\right)$ La supresión de la preferencia del varón en la sucesión al trono; $\left.2 .^{\circ}\right)$ La recepción en la Constitución del proceso de construcción europea; $3 .^{\circ}$ ) La inclusión de la denominación de las Comunidades Autónomas; 4. $^{\circ}$ ) La reforma del Senado.

22 Entre otros, pueden verse ORTEGA, L., Reforma constitucional y reforma estatutaria, Thomson-Civitas, Navarra, 2005; VERA SANTOS, J.M., ob. cit.; ROURA, S. y TAJADURA, J. (dirs.), La reforma constitucional. La organización territorial del Estado, la Unión Europea y la igualdad de género, Biblioteca Nueva, Madrid, 2005; y AA.VV., La reforma constitucional: ¿hacia un nuevo pacto constituyente?, CEPC, Madrid, 2009.

${ }^{23}$ Cfr. LÓPEZ AGUILAR, J.F., ob. cit., pp. 202 y ss. GARCÍA FERNÁNDEZ, J., ob. cit., pp. 305 y ss., identifica como motivos del fracaso: la actitud del partido popular y el hecho de que se tratara de una reforma impulsada por un partido; la obligada disolución de las Cortes y la necesidad de un referéndum; y la coincidencia 
lló un intenso proceso de reformas estatutarias, llevando a sus límites las posibilidades de descentralización política permitidas por la Constitución de 1978 (y en buena medida traspasándolos) ${ }^{24}$. Un intento fallido de mutar nuestro orden constitucional que invirtió los términos lógicos al comenzar las reformas por los Estatutos de autonomía ${ }^{25}$.

Posteriormente, tras esta "reforma constitucional fracasada» sobrevino una «reforma constitucional imprevista ${ }^{26}$. El 26 de agosto de 2011, en un contexto de crisis económica y ante las presiones del Banco Central Europeo ${ }^{27}$, los Grupos parlamentarios Socialista y Popular presentaban en el Congreso de los Diputados una iniciativa

con el debate de la reforma del Estatuto de autonomía de Cataluña. De forma más amplia véase BELDA PÉREZ-PEDRERO, E., La fallida reforma de la Constitución española durante la VIII Legislatura (2004-2008), Thomson Civitas, Navarra, 2008.

${ }^{24} \mathrm{El}$ proceso de reformas estatutarias desarrollado entre 2004 y 2011 resultó tan intenso que, como reconoce PÉREZ ROYO, J., «La reforma del estado autonómico», en AA.VV., Estudios sobre la Constitución española. Homenaje al Profesor Jordi Solé Turá, Cortes Generales, Madrid, 2008, p. 1770, no se pueden considerar propiamente como reformas sino que son nuevos Estatutos de autonomía. En particular las reformas afectaron a tres ámbitos: ampliación y precisión competencial, profundización y ampliación de las instituciones autonómicas, y previsión de instrumentos de participación y cooperación con el Estado. La primera de las Comunidades Autónomas en reformar su estatuto fue Valencia (LO 1/2006, de 10 de abril), seguida por Cataluña (LO 6/2006, de 19 de julio), Islas Baleares (LO 1/2007, de 28 de febrero), Andalucía (LO 2/2007, de 19 de marzo), Aragón (LO 5/2007, de 20 de abril), Castilla y León (LO 14/2007, de 30 de noviembre), Navarra (LO 7/2010, de 27 de octubre) y Extremadura (LO 1/2011, de 28 de enero). Los excesos de estas reformas estatutarias tuvieron que ser pulidos por el Tribunal Constitucional, en especial en sendas sentencias sobre el Estatuto de autonomía de Valencia y el de Cataluña (SSTC 247/2007, de 12 de diciembre; y 31/2010, de 28 de junio).

${ }^{25}$ En estos términos se pronuncia TORRES DEL MORAL, A., «Estado autonómico...», ob. cit, p. 50. Entre otros muchos, muy crítico con este proceso se muestra ÁLVAREZ CONDE, E., "Reflexiones sobre los actuales procesos de reforma constitucional y estatutaria», en AA.VV., Estudios sobre la Constitución española. Homenaje al Profesor Jordi Solé Turá, Cortes Generales, Madrid, 2008, p. 1504, quien reconoce que se asistió a «dos procesos paralelos que pueden presentar un elevado número de contradicciones y disfuncionalidades, tanto desde un punto de vista jurídico como político, pudiéndose hablar de una "refundación del Estado de las Autonomías" », y critica el intento de producir una especie de "relleno» por parte de normas infraconstitucionales, como son los Estatutos de Autonomía, que pudieran suponer una auténtica mutación constitucional». De manera más amplia sobre «la injustificada desconexión de estos dos procesos», vid. ORTEGA, L., ob. cit., cita en página 13.

26 Así los denomina GARCÍA FERNÁNDEZ, J., ob. cit.

27 Aunque en la correspondencia entre el Presidente del BCE, Jean-Claude Trichet, y el Presidente del Gobierno, José Luis Rodríguez Zapatero, no se recoge expresamente la petición de aquél de que se reformara la Constitución española, parece innegable que la relación entre sus peticiones y la revisión del artículo 135 de la Constitución es innegable. 
conjunta para reformar el artículo 135 de la Constitución con el propósito de recibir constitucionalmente el principio de estabilidad presupuestaria. Esta reforma se tramitó por el procedimiento de urgencia y en lectura única, desarrollándose en apenas quince días ${ }^{28}$.

Después de esta cuestionable reforma (en forma, aunque también de fondo ${ }^{29}$ ), en los últimos tiempos ha renacido intensamente el debate sobre la necesidad de revisar la Constitución ${ }^{30}$. Una mirada a los programas electorales de las principales fuerzas políticas que concurrieron a las elecciones en 2015-2016 y a los acuerdos de investidura en aquel complejo momento dan buena prueba de ello ${ }^{31}$. Más aún, en la XII Legislatura en el Congreso de los Diputados están trabajando una Subcomisión para la reforma electoral dentro de la Comisión constitucional; se ha constituido una Comisión permanente no legislativa sobre calidad democrática, contra la corrupción y para las reformas institucionales y legislativas, y en su seno hay abierta una subcomisión sobre el régimen y financiación de los partidos políticos. Además, como es sabido, a raíz de la crisis provocada por el secesionismo catalán se ha constituido una Comisión no permanente para la evaluación y la modernización del Estado autonómico. Ello sin contar otras iniciativas parlamentarias que de forma directa o indirecta inciden en materias constitucionales ${ }^{32}$. A lo que cabe sumar,

${ }^{28}$ El 30 de agosto fue tomada en consideración por el Pleno del Congreso y 7 de septiembre era votada por el Senado. En el Congreso fue aprobada por una mayoría de 316 votos a favor ( 5 en contra); y en el Senado recibió 233 votos a favor (3 en contra). El 27 de septiembre fue sancionada y promulgada por el Rey y ese mismo día fue publicada en el BOE. Los parlamentarios que se opusieron a la reforma no alcanzaron el número exigido por el artículo 167 de la Constitución para exigir la celebración del referéndum, pero sí que recurrieron en amparo la tramitación de la misma, aunque éste fue inadmitido a trámite por el Tribunal Constitucional (ATC 9/2012, de 13 de enero de 2012).

${ }_{29}$ A este respecto, entre otros trabajos, pueden verse los cuestionarios sobre la reforma de la Constitución publicados por la revista Teoría y Realidad Constitucional en su número 29 de 2012 (pp. 11-88) y por la Revista Española de Derecho Constitucional en el número 9 de 2011 (pp. 159-210).

${ }^{30}$ Según MUÑOZ MACHADO, S., Vieja..., ob. cit., p. 11, estaríamos en proceso de hacer efectiva la reforma de la Constitución "porque las aspiraciones de cambiar la Constitución se han disparado en poco tiempo».

${ }^{31}$ Salvo en el programa electoral del Partido Popular, los del PSOE, Podemos y Ciudadanos incluían propuestas de reforma de la Constitución que afectan a distintos ámbitos (instituciones y sistema político, derechos fundamentales, Estado autonómico...). También en los acuerdos de investidura suscritos entre el PSOECiudadanos y entre PP-Ciudadanos se asumían concretas propuestas de reforma constitucional.

${ }^{32}$ Sirva como ejemplo la Proposición no de Ley relativa a la reforma del Tribunal Constitucional que fue aprobada por el Pleno del Congreso de los Diputados el 28 de marzo de 2017; o la Proposición de Ley integral de lucha contra la corrupción y protección de los denunciantes que se está tramitando actualmente. 
sin lugar a dudas, las importantes contribuciones que desde el punto de vista académico están surgiendo ${ }^{33}$. Por tanto, parece oportuno acercarse a las razones que llaman en estos momentos a reformar la Constitución para valorar, en su caso, la conveniencia o necesidad de la misma, y su mayor o menor urgencia.

\section{RAZONES DE LA CONVENIENCIA, AUNQUE NO URGENTE NECESIDAD, DE REFORMAR LA CONSTITUCIÓN DE 1978}

Han transcurrido cuatro décadas desde la aprobación de la Constitución española de 1978 y, lo cierto, es que los tiempos cambian y «se producen desarmonías entre una constitución y la realidad social» ${ }^{34}$. Cuando esto ocurre, una de las funciones del jurista ha de ser ayudar a reconocer los factores que pueden estar tensionando la Constitución, su vigencia y fuerza normativa. De lo cual se podrá deducir entonces la necesidad o no de su reforma.

Atendiendo a nuestra Constitución de 1978 y a la realidad social de 2018 , creo que una primera razón que abunda en la conveniencia de afrontar la reforma constitucional vendría dada por los notables cambios que se han producido en los últimos tiempos en las condiciones socio-económicas de nuestro país y, en general, en todo el mundo. Por citar sólo algunos factores: han aparecido nuevos fenómenos como Internet y las TICs que han dado origen a una auténtica revolución; la globalización y la variedad cultural de nuestras sociedades es hoy una realidad; la integración europea ha tenido un notable impacto en nuestras estructuras políticas y en las relaciones económicas y sociales; y la situación económica y la mentalidad y usos de los españoles actuales quedan muy lejos de los de la sociedad que inauguró nuestra democracia. De forma que tan intensos cambios socio-económicos es lógico que hayan terminado afectando

${ }^{33}$ Entre los últimos destacan las «Ideas para una reforma de la Constitución» que en noviembre de 2017 han presentado un grupo de profesores de distintas universidades españolas encabezados por Santiago Muñoz Machado. Pero también pueden destacarse: RUIZ-RICO RUIZ, G. et al. (coords.), Regeneración democrática y reforma constitucional, Tirant lo Blanch, Valencia, 2017; ÁLVAREZ CONDE, E. (dir.), Reflexiones y propuestas sobre la reforma de la Constitución española, Comares, Granada, 2017; FREIXES SANJUÁN, T. y GAVARA DE CARA, J.C. (coords.), Repensar la constitución. Ideas para una reforma de la Constitución de 1978: reforma y comunicación dialógica. Parte primera, CEPC-BOE, Madrid, 2016; HERRERO DE MIÑÓN, M., Tres conferencias sobre la reforma constitucional, Tirant lo Blanch, Valencia, 2016; PÉREZ ROYO, J., La reforma constitucional inviable, ob. cit.; y GARCÍA ROCA, J. (ed.), Pautas..., ob. cit.

${ }^{34}$ GARCÍA ROCA, J., "De la revisión de las constituciones...», ob. cit., p. 211, con remisión a WHEARE, K.C., ob. cit., pp. 76-83. 
a nuestra Norma Fundamental. Piénsese, por ejemplo, a la interpretación en buena medida mutadora que tuvo que hacer el Tribunal Constitucional del artículo 32 de la Constitución para legitimar el matrimonio homosexual ${ }^{35}$; en las nuevas problemáticas a las que se enfrentan legislador y tribunales en relación con la protección y garantía de derechos fundamentales ante los desarrollos tecnológicos; o en la «contracción» sufrida por nuestra Constitución económica por mor de las restricciones que impone la Unión Europea a la intervención pública en el libre mercado.

Asimismo, en segundo lugar, debe destacarse que en España se vive una evidente crisis de nuestra democracia representativa agravada por la crisis económica ${ }^{36}$. El movimiento del 15-M con sus exigencias de «más democracia» y sus consignas de «no nos representan» constituyó un ejemplo paradigmático de ello. Una desafección política que se mantiene en el tiempo y se demuestra en cada barómetro social donde se reconoce a los políticos y a la política como uno de los problemas del país. Lo cual se ha visto empeorado aún más por la quiebra político-social en Cataluña y, más en general, en relación con la organización territorial del poder ${ }^{37}$. Lo cierto es que desde hace tiempo en nuestro país «avanza inexorablemente el proceso de deterioro de las instituciones constitucionales» ${ }^{38}$. Pero es que, además, en buena medida ha desaparecido el sustrato político que caracterizó a la Transición, como se puso de manifiesto con la abdicación del Rey Juan Carlos y con la aparición de nuevos partidos políticos con amplia acogida popular en los últimos procesos electorales. Al mismo tiempo que se han superado algunas de las razones que justificaron relevantes decisiones constitucionales en relación con nuestro sistema político ${ }^{39}$ y que han provocado ciertos

35 STC 198/2012, de 6 de noviembre.

36 Cfr. GARRORENA MORALES, A., Escritos sobre la democracia. La democracia y la crisis de la democracia representativa, CEPC, Madrid, 2014, pp. 187-188, sobre la crisis actual de la democracia representativa y sus signos más evidentes.

37 A este respecto puede verse la descripción que hace PÉREZ ROYO, J., La reforma constitucional inviable, ob. cit., pp. 33 y ss., de la crisis del sistema de partidos de la transición. Este autor considera que el sistema bipartidista habría garantizado cuatro décadas de estabilidad política pero actualmente se encuentra en "proceso de colapso» (p. 35). Sitúa los indicadores de esta desafección a partir de 2008 , con la crisis económica, pero en 2015 son ya patentes (p. 37-38), como consecuencia de la "pésima» gestión de la crisis económica y del fracaso de la renovación de la Constitución territorial.

${ }^{38}$ MUÑOZ MACHADO, S., Informe sobre España, Crítica, Barcelona, 2012, p. 9.

39 Siguiendo la explicación que ofrece FERNÁNDEZ-MIRANDA CAMPOAMOR, A., «Sobre la forma de gobierno: ¿un exceso de racionalización?», en GACÍA ROCA, J. y ALBERTI, E. (coords.), Treinta años de Constitución, Tirant lo Blanch, Valencia, 2010, p. 855, sobre el constituyente se ciñeron dos fantasmas que condicionaron el 
«defecto[s] de forma $»^{40}$ de los que en buena medida derivan algunas de sus más acuciantes «debilidades» ${ }^{41}$. Unos defectos de diseño que reclaman la introducción de reformas, las cuales como se estudiará puede resultar conveniente que alcancen a la Constitución.

Unido a estos aspectos, en tercer lugar, la conveniencia de reforzar la legitimación inter-generacional de la Constitución a través de su reforma también se presenta como un factor a considerar ${ }^{42}$. La teoría clásica ya descartó imponer plazos fijos para reformar la constitución, limitando así su vigencia, pero ello no resta una evidente lucidez al planteamiento de Jefferson ${ }^{43}$. Es cierto que no sólo

diseño de nuestro sistema político: por un lado, el fantasma de la fragmentación parlamentaria; y, por otro, el fantasma de la debilidad partidista. Ocurre que mientras «[e]l primero descans[ó] en una percepción equivocada; el segundo [lo hizo] en una percepción certera pero sujeta inexorablemente a plazo de caducidad, "certus an et incertus quando"». Esta explicación nos parece más convincente que la que ofrece PÉREZ ROYO, J., La reforma constitucional inviable, ob. cit., pp. 99 cuando imputa al Rey y al Presidente Suárez el objetivo de lograr una «desviación calculada de la igualdad en la ley» en la Ley para la reforma política a los efectos de que los partidos de centro-derecha obtuvieran una mayoría holgada con la que proceder a la elaboración de la Constitución, consolidando así una «constitución monárquica, bipartidista y antifederal». Pues bien, aunque se pueda compartir que en nuestro sistema electoral existe una «desviación calculada de la igualdad en la ley», según acabo de decir, parece razonable que ésta trajo causa de las razones que ofrece el profesor Fernández-Miranda más que en un intento de controlar el sistema político.

${ }^{40}$ RUBIO LLORENTE, F., "Defectos de forma», ob. cit., pp. 138 y ss. De manera más radical en su exposición, véase PÉREZ ROYO, J., La reforma constitucional inviable, ob. cit., pp. 33 y ss.

${ }^{41}$ En concreto, FERNÁNDEZ-MIRANDA CAMPOAMOR, A., ob. cit., p. 866, identifica las siguientes: «De un lado, un acusado desequilibrio entre los poderes claramente favorable al Poder Ejecutivo y, dentro de éste, una fuerte tendencia a la presidencialización que en la práctica amenaza con diluir y absorber al Gobierno como órgano colegiado. Y, de otro, una no menos fuerte deriva del sistema hacia la partitocracia».

42 Siguiendo a PÉREZ ROYO, J., La reforma constitucional inviable, ob. cit., pp. 29-30, ha de entenderse que «La reforma es la institución mediante la que se renueva el vínculo entre la legitimidad de origen y la legitimidad de ejercicio en el Estado constitucional. Un Estado no puede vivir indefinidamente de la legitimidad constituyente originaria, por muy fuerte que esta sea. El paso del tiempo inevitablemente debilita dicha legitimidad y puede llegar a hacerla desaparecer. Esta es la razón por la que las constituciones tienen cláusulas de reforma. Para que se pueda renovar de manera jurídicamente ordenada la voluntad constituyente originaria».

${ }^{43}$ Jefferson, como se recoge en El Federalista, concluía que la tierra se ha hecho «para el uso de los vivos y no de los muertos», de lo que deducía que la Constitución debía revisarse aproximadamente cada dos décadas. Una línea argumental que fue igualmente defendida por Paine y en Francia también Sieyès en la presentación de la Declaración de Derechos francesa sostuvo que sería conveniente fijar períodos fijos para la revisión de la Constitución. Por su parte, la Constitución francesa de 1973 acogió en buena medida estas tesis y declaró con rotundidad en su artículo 28: «Un pueblo tiene siempre el derecho a revisar, reformar y cambiar su Constitución. Una generación no puede someter a sus leyes a las generaciones futuras». Sin llegar 
a través de la reforma se puede cultivar un patriotismo constitucional entre las generaciones que no votaron una Constitución. Si sus principios basilares están bien asentados estos pueden compartirse fácilmente por sucesivas generaciones, del mismo modo que si aquella que es la norma suprema demuestra un carácter abierto y flexible podrá desarrollarse y actualizarse para adecuarse a las nuevas «exigencias políticas» en muchas ocasiones sin necesidad de revisión formal ${ }^{44}$. Ahora bien, como nos recuerda García Roca, hay un factor de especial interés: «La reforma recuerda al pueblo su soberanía: [...] permite al pueblo visualizar su propia soberanía frente al gobierno de unos pocos representantes. Toda democracia representativa es elitista, al venir fundada en elecciones, mientras la reforma apodera y fortalece al pueblo como verdadero sujeto de la democracia ${ }^{45}$.

De esta guisa, no comparto la visión de quienes sostienen que en nuestro país el consenso social sobre la Constitución está acabado, ni otras teorías más depuradas dogmáticamente que advierten un defecto de legitimidad de origen en nuestro proyecto constitucional ${ }^{46}$.

a estos extremos que, como reconoce RUBIO LLORENTE, F., «Rigidez...», ob. cit., p. 22, llevaban a "sacrificar el constitucionalismo a la democracia, de manera que la fuerza vinculante de la Constitución no se extendiera a quienes no pudieran consentirla», se terminó imponiendo la tesis más moderada de Madison quien apostó por dar con un sistema que protegiera «por igual contra la facilidad extrema [de la reforma], que haría a la Constitución demasiado variable (...) y contra la exagerada dificultad, que perpetuaría sus defectos manifiestos» (citas de El Federalista tomadas de GARRORENA MORALES, A., Derecho constitucional. Teoría de la Constitución y sistema de fuentes, CEPC, Madrid, 2014, p. 100). De ahí el procedimiento rígido de reforma de la Constitución de los Estados Unidos previsto en su artículo V o el de la Constitución francesa de 1791.

${ }^{44}$ Como se hace notar en la ya clásica obra de WHEARE, K.C., Las constituciones modernas, Ed. Labor, Barcelona, 1971, pp. 73 y ss., una Constitución puede cambiar a través de una enmienda formal a la misma, pero también por mor de decisiones judiciales o por el desarrollo de usos y convenciones, incluso legales. Entraríamos así dentro de lo que la doctrina ha denominado «mutaciones constitucionales». Sobre la mutación constitucional en n GARCÍA ROCA, J., «De la revisión de las constituciones...», ob. cit., p. 182, y GARCÍA-ATANCE, M.V., ob. cit., pp. 96 y ss., se encuentran reflexiones interesantes y nutridas referencias bibliográficas.

45 GARCÍA ROCA, J., "De la revisión de las constituciones...», ob. cit., p. 215. A este respecto, puede verse especialmente DE VEGA, P., ob. cit., pp. 53 y ss., y RUBIO LLORENTE, F., «Rigidez...», ob. cit., 20 y ss. Más recientemente, MUÑOZ MACHADO, S., Vieja..., ob. cit., pp. 15 y ss. recupera a los clásicos para responder a la pregunta «¿Pueden las generaciones pasadas imponer una constitución a las generaciones siguientes?».

46 Esta es la tesis que sostiene PÉREZ ROYO, J., La reforma constitucional inviable, ob. cit., passim, especialmente pp. 99, 132-139, a cuyo juicio la «desviación calculada de la igualdad en la ley» fijada en la Ley para la reforma política a la que antes se ha hecho referencia, se mantuvo en la Constitución de 1978. Lo cual le lleva a concluir que «el principio de construcción de la democracia está viciado de origen» 
De hecho, a lo largo de este trabajo trataré de defender la vigencia del mismo. Sin embargo, teniendo en cuenta todas las circunstancias antes señaladas - la severa crisis económica que ha terminado menoscabando seriamente nuestra democracia representativa y sus instituciones, los evidentes cambios sociales y la profunda quiebra territorial vivida-, considero que la reforma de la Constitución, a través de un proceso rígido que reclama diálogo político y exige generar consensos, el cual, además, debería llamar a la participación directa del pueblo, puede ser el mejor de los cauces posibles para afrontar tan crítica situación político-institucional y superar el desafecto social que conlleva, volviendo a motivar a las generaciones más jóvenes con los valores de nuestra democracia y del orden constitucional. Eso sí, este proceso habrá de afrontarse con cautelas —como se expondrá en los siguientes apartados- para evitar algo parecido a lo ocurrido en Italia donde los jóvenes han terminado rechazando la reforma constitucional invirtiendo los términos jeffersonianos: «los hijos han rechazado el nuevo orden constitucional propuesto por los padres, retomando el lazo espiritual de los abuelos muertos ${ }^{47}$.

Por último, en cuarto lugar, también se presentan razones de técnica jurídica que justificarían la reforma. Una constitución, como cualquier otra norma, siempre es perfectible ${ }^{48}$. Algo que se va mostrando de forma cada vez más evidente con el paso del tiempo, que pone al descubierto la obsolescencia de ciertos preceptos o las deficiencias técnicas de los mismos (por ejemplo, los «defectos de forma» antes señalados). A mayor abundamiento, en nuestra Constitución se encuentran cuestiones que quedaron abiertas porque el constituyente no fue capaz de alcanzar un acuerdo, dejando su definición en manos de los actores políticos de cada momento, de sus luchas y conflictos. Al final, esta falta de claridad ha dado lugar a tensiones políticas y ha sido fuente de litigiosidad por tratarse de as-

(p. 133) y hemos vivido con un «déficit de legitimidad democrática» en la definición constitucional del Estado (p. 139). Llegando a calificar a la Constitución de 1978 como «vergonzante» (p. 132).

47 VESPAZIANI, A., "El referéndum constitucional y la saga de las reformas institucionales en Italia: much ado about nothing», Revista de Derecho constitucional europeo, n. 27, 2017, pp. 1-20. Quien añade: «El patriotismo constitucional italiano contemporáneo se parece así a la constitutional faith estadounidense: una fe radicada en los valores originarios y una fidelidad a la generaciones pasadas, opuesta de modo polémico a los intentos de reforma de los elementos institucionales disfuncionales, propuestos por políticos vivos, frente a los que la desconfianza es máxima y muy debilísima su legitimación social».

${ }_{48}$ Véase, por ejemplo, LÓPEZ AGUILAR, J.F., ob. cit., p. 205 quien se refiere a «La Constitución irreformada: normas atemporales, obsoletas, superadas, virtuales», y, con más amplitud, entre otros muchos, recomiendo la revisión técnica realizada en GARCÍA ROCA, J. (ed.), Pautas..., ob. cit. 
pectos materialmente constitucionales que reclaman un cierto blindaje. Así ha ocurrido con la Constitución territorial, que sin duda supone el aspecto más conflictivo que exige una respuesta ${ }^{49}$. Los gravísimos intentos de quiebra que han llevado a que por primera vez se haya tenido que activar el artículo 155 de la Constitución como cláusula excepcional para intervenir ante la insurgencia de los poderes públicos de una Comunidad Autónoma en octubre de 2017 son sólo un ejemplo. Las tensiones provocadas por el Plan Ibarretxe y en general el intento de falseamiento de la Constitución a través de las últimas reformas estatutarias antes indicadas, o los continuos litigios competenciales, y las demandas de casi todos los territorios de España de una mejor financiación autonómica atestiguan la existencia de unas demandas políticas que no encuentran adecuado acomodo en la Constitución de 1978 y que no han podido satisfacerse de manera correcta a través de reformas infra-constitucionales.

Así las cosas, a la luz de todo lo dicho se observa como «[a] pesar de su juventud la Constitución ha sufrido el ritmo de intensa aceleración histórica de este período en España ${ }^{50}$. Existen «exigencias políticas» que afectan a aspectos constitucionales a las que no se está dando respuesta ${ }^{51}$, lo cual tensiona y puede terminar menoscabando la vigencia y legitimidad de nuestra Constitución ${ }^{52}$. Sin embargo, el reconocimiento de estas poderosas razones no me lleva a

49 El sintético diagnóstico de ARROYO GIL, A., «¿El orden federal alemán como modelo para el futuro del Estado autonómico español?», en AA.VV., La Constitución politica de España, CEPC, Madrid, 2016, p. 393, creo que es compartido mayoritariamente por la doctrina: «Las prescripciones constitucionales sobre organización territorial del Estado, o bien han quedado obsoletas, o bien están necesitadas de reforma o actualización, con el fin de resolver viejos problemas y de dotar a nuestra forma territorial de Estado de mejores mimbres constitucionales». Como se verá, RUBIO LLORENTE, F., "Defectos de forma», ob. cit., y «Rigidez y rigor mortis», ob. cit., se refiere al problema territorial como el «nudo gordiano del constitucionalismo español».

50 TORRES DEL MORAL, A., «Estado autonómico...», ob. cit., p. 39.

51 A este respecto, preguntándose sobre cuándo es necesaria la reforma constitucional, creo que sigue siendo válida la respuesta que en su día dio el profesor DE VEGA, P., ob. cit., p. 93: aunque toda reforma comporta «riesgos para el prestigio y la propia eficacia de la normatividad de la ley fundamental», será políticamente conveniente si jurídicamente es necesaria, algo que se constatará cuando las posibilidades de interpretación aprovechando el carácter abierto de la propia constitución lleguen a su límite. De forma que «si las exigencias políticas obligan a interpretar el contenido de las normas de forma distinta a lo que las normas significan, es entonces cuando la reforma se hace jurídica y formalmente necesaria. En toda situación límite no cabe otro dilema que el de falsear la Constitución o reformarla».

${ }^{52}$ Como señala LÓPEZ AGUILAR, J.F., ob. cit., p. 205, la falta de reforma de la Constitución ha tenido efectos «sobre su normatividad y sobre su centralidad integradora ante los cambios de la realidad social sobre la que opera». 
concluir que la reforma sea «necesaria» y menos aún «urgente», aunque sí que entiendo que resulta altamente «conveniente». La conveniencia creo que ha quedado suficientemente justificada: la reforma constitucional puede ser una vía excelente para dar las respuestas normativas que reclaman las exigencias políticas antes presentadas. Pero, ¿por qué no la entiendo necesaria? Fundamentalmente por una razón: porque considero que el carácter abierto de la Constitución hace que la misma no imponga ningún límite insoslayable a las exigencias políticas de este momento. Si la Constitución española hubiera sido incompatible con el principio de primacía del Derecho europeo o no hubiera permitido la integración en la UE; si no permitiera explorar mejoras en nuestro sistema electoral o en el funcionamiento de nuestro sistema político; si fuera a dar lugar a una discriminación intolerable en la sucesión a la Corona; si no permitiera margen para enfrentarse a los problemas territoriales de nuestro país; si no diera adecuada protección a los derechos de las personas ante las nuevas realidades; si los ciudadanos no se sintieran identificados con los principios y valores fundamentales sobre los que se levanta el edificio constitucional, entonces sí que estaríamos hablando de necesidad. Pero no es el caso. De hecho, siendo hoy día la cuestión territorial el problema constitucional más grave de nuestro país y el que en la Constitución queda más abierto y con mayores imperfecciones, creo sinceramente que si hubiera lealtad entre los actores políticos el mismo se vería de otra forma. Todo lo cual no perjudica que, entre las distintas vías para afrontar tales demandas sociales y políticas, mantenga que para muchas de ellas la reforma constitucional es la mejor. De ahí su conveniencia, reitero.

Asimismo, he descartado que la misma deba afrontarse con «urgencias». Aunque comparto que hay que «desdramatizar» la reforma constitucional ${ }^{53}$, lejos de aquél «con temor y temblor» ${ }^{54}$ con el que el profesor Lucas Verdú consideraba que había que acercarse a la revisión constitucional; al final la reforma de la Constitución, especialmente si va a afectar a aspectos profundos referidos a demandas sociales complejas, requiere serenidad y prudencia ${ }^{55}$, y debe huir de

53 GARCÍA ROCA, J., «De la revisión de las constituciones...», ob. cit., p. 189. Y, en sentido similar, cfr. GARCÍA ROCA, J. (ed.), Pautas..., ob. cit.

${ }^{54}$ LUCAS VERDÚ, P., «Prólogo», en GARCÍA-ATANCE, M.V., ob. cit., p. 16.

55 Como advierte DE CARRERAS SERRA, F., "Conveniencia...», ob. cit., "la reforma de aspectos fundamentales de una constitución debe hacerse con cautela, empleando inteligencia jurídica y prudencia política». Aportando algunos requisitos técnicos y de prudencia política, vid. TORRES DEL MORAL, A., «Estado autonómico...», ob. cit, p. 40. 
«reformas precipitadas» ${ }^{56}$. No hay que preocuparse si forjar las respuestas adecuadas requiere varios años de diálogo político, social y jurídico. Debe cocinarse a fuego muy lento ${ }^{57}$. No en vano está en juego la norma fundamental de la comunidad política.

$\mathrm{Y}$, sobre estas premisas, pasemos a delinear cuál podría ser el perímetro de esta conveniente reforma constitucional. Conscientes, en todo caso, de que las exigencias que se han identificado afectan, según se ha visto, a cuestiones materialmente constitucionales, pero no todas ellas reclaman una intervención en la Constitución. De manera que lo que pueda reformarse a través de leyes, mejor hacerlo asi $i^{58}$ para no caer en una "hipertrofia de la reforma» ${ }^{59}$. Ahora bien, metodológicamente puede ser positivo afrontar su discusión conjuntamente. En este sentido hay que apostar por una cierta «economía» y, sobre todo, por garantizar la «sobriedad constitucional» y el "rigor normativo» ${ }^{60}$. Así, el objetivo ahora es el de proyectar sobre la regulación constitucional las necesidades políticas antes destacadas para identificar los aspectos que reclaman reformas, discerniendo allí donde la intervención constitucional resulta imprescindible y donde no, aunque ésta pudiera ayudar a avanzar más. No se entrará

56 GARCÍA ROCA, J., «De la revisión de las constituciones...», ob. cit., p. 188, quien explica que «Extremada urgencia en la tramitación y reforma de una norma con autoridad suprema y por definición estable es una contradicción en sustancia». En GARCÍA ROCA, J. (ed.), Pautas..., ob. cit., p. 129 se matiza también la exigencia de urgencia y concluye que en nuestro país «se trata de una acción urgente, pero que sólo puede hacerse al ritmo sosegado de un procedimiento constitucional adecuado".

57 Así, GARCÍA ROCA, J., «De la revisión de las constituciones.... ob. cit.,p. 188: «Una reforma constitucional no puede precipitarse sin merma de su eficacia, legitimidad democrática y virtualidad integradora. Es un guiso a fuego lento siguiendo un procedimiento sosegado, participativo y deliberativo, porque el resultado debe ser inclusivo».

${ }^{58}$ De forma contundente reconoce DE CARRERAS SERRA, F., "Conveniencia...», ob. cit., que "Lo que pueda reformarse por ley, hágase así y luego ya se incorporará a la Constitución». En este sentido, destaca TORRES DEL MORAL, A., "¿Reforma constitucional o reforma política?», en RUIZ-RICO RUIZ, G. et al. (coords.), Regeneración democrática y reforma constitucional, Tirant lo Blanch, Valencia, 2017, pp. 23 y ss., que la primera medida debe ser la de discriminar las materias para no incluir en la reforma constitucional las que pueden ser reguladas por ley, $\mathrm{y}$, en tal sentido, propone toda una serie de reformas subconstitucionales (pp. 27 y ss.). El propio RUBIO LLORENTE, F., «Defectos de forma», ob. cit., p. 133, afirmaba a este respecto que: «La configuración actual del poder en España adolece de defectos, en algunos casos (los menos) origen en la propia Constitución y en muchos en insuficiencias de las normas subconstitucionales. A veces porque la regulación jurídica tiene efectos disfuncionales, pero más frecuentemente por no haber servido para impedir o corregir prácticas viciosas».

${ }^{59}$ GARCÍA ROCA, J., «De la revisión de las constituciones...», ob. cit., p. 202.

60 Ibidem. 
a detallar el contenido de las reformas, sino sólo su perímetro, señalando aquellos puntos que pueden resultar especialmente controvertidos. Pero antes, indaguemos sobre la intensidad de esta posible reforma constitucional.

\section{IV. «MOMENTO REFORMISTA», QUE NO CONSTITUYENTE}

Siendo poderosas las razones que reclaman la reforma constitucional, surge entonces de forma espontánea la pregunta: ¿Vive España un nuevo «momento constituyente»? ¿Debe emprenderse una revisión total de la constitución?

Un debate clásico ha sido el que ha versado sobre el carácter limitado del poder de reforma constitucional, cuestionando en términos de legitimidad la posibilidad de recurrir al poder de reforma constitucional para acabar con una Constitución ${ }^{61}$, aquello que se llamó «fraude a la constitución» ${ }^{62}$. Ello porque «una reforma no es un atentado a la constitución sino una actualización de la misma», asumiendo como límite implícito a su propio poder el respeto a la identidad constitucional ${ }^{63}$. Sin embargo, en la medida que normativamente se prevé la posibilidad de revisión total de una constitución, como hace la Constitución española en su artículo 168, desde una perspectiva normativa no puede evitarse la reforma total de la misma. Por tanto, quede claro que a mi entender, de constitutione lata, sería posible emprender una demolición de nuestra Constitución vía artículo 168 para levantar una de planta radicalmente dife-

${ }^{61}$ GARCÍA ROCA, J., «De la revisión de las constituciones...», ob. cit., pp. 189 y en particular su nota a pie 38, donde recoge el debate entre Mortati y Biscaretti sobre en qué medida una constitución puede abrir la puerta a la revocación de sus decisiones políticas básicas y mantener al mismo tiempo su pretensión de legitimidad de partida. En general, sobre los límites al poder de reforma constitucional, vid. DE VEGA, P., ob. cit., p. 65.

${ }^{62}$ En nuestra doctrina, como señala VERA SANTOS, J.M., ob. cit., p. 34, a la reforma total de la Constitución siguiendo los procedimientos constitucionales se le ha denominado indistintamente "revisión» o "sustitución» de la Constitución. Fue SCHMITT, C. Teoría de la Constitución, Alianza, Madrid, 1982, pp. 155 y ss., quien de forma precisa distinguió entre los casos de destrucción, supresión y quebrantamiento constitucional.

${ }^{63}$ GARCÍA ROCA, J., "De la revisión de las constituciones...», ob. cit., p. 184. Sobre la "fórmula política» del Estado como elemento objetivo de la identidad constitucional, vid. GARCÍA-ATANCE, M.V., ob. cit., pp. 142, que llega a afirmar ésta como limite absoluto del poder de reforma. En general sobre los límites a la reforma constitucional, vid. DE VEGA, P., ob. cit., pp. 217 y ss. 
rente $^{64}$. Cuestión distinta es si esto es deseable o no. Y en este último punto se centrarán las siguientes reflexiones.

La Constitución española de 1978 erige un Estado social y democrático de Derecho, siendo su forma política la monarquía parlamentaria, y ha permitido la consolidación de un Estado de las autonomías donde las «nacionalidades y regiones» que integran nuestra «patria común» gozan de un amplio autogobierno (arts. 1 y $2 \mathrm{CE}$ ). Un orden constitucional que residencia la soberanía en el "pueblo español», proclamando como valores superiores «la libertad, la justicia, la igualdad y el pluralismo político» (art. $1 \mathrm{CE}$ ), al tiempo que reconoce la dignidad humana, los derechos inviolables de la persona y su libre desarrollo de la personalidad, así como el respeto a la ley, como "fundamento del orden político y de la paz social» (art. 10.1 CE). Todo ello sintetiza los pilares y la estructura sobre los que se levanta la Constitución española de 1978, su identidad constitucional. Algo que creo que es bueno recordar frente a aquellos que postulan abrir ahora un proceso constituyente en España ${ }^{65}$. Una propuesta que, como sostuvo Rubio Llorente en un artículo publicado pocas semanas antes de su fallecimiento, supone una auténtica "insensatez» ${ }^{66}$.

En este sentido, conforme ha señalado Díaz Revorio ${ }^{67}$, cualquier modificación que afectara a los valores y principios fundamentales

${ }^{64}$ Así lo comparten, entre otros, GARCÍA-ESCUDERO MÁRQUEZ, P., El procedimiento agravado de reforma de la Constitución de 1978, CEPC, Madrid, 2007, p. 142; y DÍAZ REVORIO, F.J., "Consideraciones sobre la reforma...», ob. cit., p. 605. En contra, véase GARCÍA-ATANCE, M.V., ob. cit., pp. 278 y ss.

65 Actualmente, además de los partidos independentistas, el partido político nacional más relevante cuyos dirigentes han llamado a derrocar lo que denominan el "régimen del 78» y a abrir un nuevo proceso constituyente es Podemos. Puede recordarse a modo de ejemplo el discurso de Pablo Iglesias cuando en 2014 asumió la secretaría general del Partido. Una referencia a esto puede verse en El País, «Pablo Iglesias promete acabar con el "régimen" de la Transición», 16/11/2014: https:// politica.elpais.com/politica/2014/11/15/actualidad/1416044494_928494.html

${ }^{66}$ RUBIO LLORENTE, F., «Proceso constituyente, clamor popular y otros desvaríos», Ahora, 16/12/2015.

${ }^{67}$ DÍAZ REVORIO, F.J., "Consideraciones sobre la reforma de la Constitución española desde la teoría de la Constitución», en VERA SANTOS, J.M. y DÍAZ REVORIO, F.J. (coords.), La reforma estatutaria y constitucional, La Ley, Madrid, 2009, p. 604, diferencia en la Constitución aquellos «valores que determinan la legitimidad del sistema constitucional» (valores superiores, soberanía popular, dignidad de la persona, derechos inviolables y libre desarrollo de la personalidad), de las «decisiones políticas fundamentales no estrictamente vinculadas a la legitimidad del sistema» (Monarquía parlamentaria y unidad de la nación con reconocimiento del principio del Estado autonómico). La supresión o alteración de cualquiera de ellos conllevaría un cambio de sistema constitucional, pero sólo respecto de los primeros cabría hacer un reproche en términos de legitimidad al ordenamiento constitucional resultante. 
de nuestra Constitución habría de reputarla ilegítima. Una reforma del tipo supondría salirse de los contenidos propios del constitucionalismo liberal-democrático y muy probablemente nos llevaría, como advertía Rubio Llorente, a un proyecto rupturista que «nos devolvería al mundo de enfrentamientos violentos que en 1978 quisimos dejar atrás para siempre ${ }^{68}$; amén de que nos alejaría de Europa $^{69}$. Distinto sería si lo que se pretende alterar son las «decisiones políticas fundamentales no estrictamente vinculadas a la legitimidad del sistema», retomando nuevamente la distinción de Díaz Revorio $^{70}$. En particular, sería el caso de que se apostara por acabar con la monarquía, con el sistema parlamentario, o con la descentralización política. Propuestas de este tipo no pueden reputarse ilegítimas, pero debe reconocerse que las mismas implicarían introducir cambios sustanciales en la estructura de la Constitución de 1978. A partir de ahí, en un cálculo de costes y beneficios, considero que aquellos serían muy altos para los escasos beneficios que podrían derivarse $^{71}$. De hecho, ninguna de las demandas político sociales que han podido identificarse afectaría a estos elementos estructurales. Ni siquiera un cambio hacia un Estado federal comportaría a mi juicio tal afectación porque, como se verá, hoy por hoy creo que nuestro Estado de las autonomías funciona como tal (cuestión distinta, como se verá, es que se pretenda dar virtualidad jurídica a un Estado plurinacional que pasara a configurar una suerte de Estado confederal — con derecho de autodeterminación incluido-).

Es por ello que concluyo reconociendo que la Constitución de 1978 sigue siendo una obra de gran calidad técnica y moderna, con unos pilares y una estructura sólidos. Asumo el presupuesto que sobre el porqué y el cómo reformar han afirmado los profesores que han participado en la elaboración de Ideas para una reforma de la constitución: «No se trata, por tanto, de iniciar un proceso constituyente sino un proceso de reforma constitucional. Defendemos el mantenimiento de los fundamentos sobre los que se asienta la Constitución de 1978, que son los valores europeos, y planteamos la modificación de algunos contenidos.» ${ }^{72}$. Estamos, por tanto, ante un

68 RUBIO LLORENTE, F., «Proceso constituyente...», ob. cit.

${ }^{69}$ Aunque en nuestro país no han tenido acogida, piénsese en la involución que están viviendo en términos democráticos y de garantía de los derechos fundamentales países como Hungría o Polonia, ante los que la Comisión Europea ha tenido que valorar la apertura de procesos por infracción del Estado de Derecho, de los principios democráticos y de los derechos fundamentales.

${ }^{70}$ DÍAZ REVORIO, F.J., "Consideraciones sobre la reforma...», ob. cit., p. 604.

71 Así, TORRES DEL MORAL, A., "¿Reforma constitucional...», ob. cit., p. 24.

72 AA.VV., Ideas para una reforma de la Constitución, Noviembre 2017. 
momento reformista, que no constituyente. Algo que, por cierto, no es exclusivo de España sino que la aceleración histórica en la que vivimos afecta también al resto de países y son muchos los Estados de nuestro entorno que han acometido con desigual suerte proyectos reformistas de sus constituciones, sin que ninguno de ellos, eso sí, se haya lanzado a aventuras rupturistas ${ }^{73}$.

\section{EL PERÍMETRO DE LA REFORMA CONSTITUCIONAL POSIBLE}

\section{V.1. Modelo territorial y reforma del Senado}

Parece evidente que actualmente el problema constitucional más grave al que se enfrenta España es el de la quiebra de su Constitución territorial, conforme a lo que hemos señalado anteriormente. Ahora bien, como expresa Blanco Valdés, «en España no tenemos un problema territorial, sino dos: el que plantean los nacionalismos y el derivado del mal funcionamiento del Estado autonómico», con la advertencia añadida de que si se quiere arreglar el primer problema en el sentido planteado por «los nacionalistas y sus aliados, empeoraremos el segundo, sin garantía de que los impulsores del nacionalismo no se revuelvan de nuevo dentro de nada ${ }^{74}$. Así las cosas, en la medida que se comparte esa opinión, la delimitación aquí esbozada atenderá a las cuestiones que afectan al funcionamiento general del Estado autonómico, más que a las infundadas demandas de los nacionalismos independentistas ${ }^{75}$. No en vano estos úl-

${ }^{73}$ Entre otros países podemos destacar Alemania, que reformó intensamente su sistema federal entre los años 2006 y 2009 y todavía hoy sigue abierto este proceso reformista; Francia en 2014 racionalizó su Estado regional; e Italia intentó fallidamente una amplia reforma de sus sistema político en 2016.

${ }^{74}$ Véase La voz de Galicia, «La prioridad es la reforma», 06/12/2017. Texto accesible en: https://www.lavozdegalicia.es/noticia/espana/2017/12/06/prioridad-reformaterritorial/0003_201712G6P8991.htm. De este autor pueden verse, entre otros, BLANCO VALDÉS, R., El laberinto territorial español: del cantón de Cartagena al secesionismo catalán, Alianza, Madrid, 2014; y Los rostros del federalismo, Alianza, Madrid, 2012.

${ }^{75}$ Como responde BLANCO VALDÉS, R., «¿Por qué la federalización de España no ha colmado la reivindicación nacionalista?» en AA.VV., La Constitución política de España, CEPC, Madrid, 2016, pp. 426 y ss., no parece que puedan sustentarse con un mínimo de objetividad las quejas sobre el grado de descentralización de España en las que se basan las reivindicaciones secesionistas. Y, en este sentido, comparto con ARROYO GIL, A., "¿El orden federal alemán...», ob. cit., p. 394, que no hay que buscar respuestas rápidas y concretas frente al envite secesionista catalán, sino afrontar una reforma «meditada y de calado de nuestra ley básica» que aborde el aspecto territorial. 
timos, junto a los populismos, son los dos principales «enemigos culturales del constitucionalismo democrático», en palabras de Fernando Rey ${ }^{76}$.

Como es sabido, la Constitución de 1978 dejó la cuestión territorial abierta, quedó «deconstitucionalizada», en expresión afortunada del profesor Cruz Villalón. Si bien, con sus luces y sus sombras ${ }^{77}$, el modelo se ha ido consolidando merced a los distintos pactos políticos, al desarrollo de los Estatutos de autonomía como bloque de constitucionalidad y a la jurisprudencia del Tribunal Constitucional. Hasta el punto de que hoy puede advertirse una auténtica mutación constitucional donde el Estado de las autonomías ha pasado a reconocerse como la Constitución territorial de nuestro país ${ }^{78}$. No obstante lo cual, y a pesar de que el Estado de las autonomías ha ido adquiriendo rasgos federalizantes, la falta de un acuerdo global sobre el mismo y su desarrollo casi podría decirse que por aluvión provocan tensiones constantes y demandas de introducir correcciones al mismo ${ }^{79}$. Unas tensiones que se han desbordado cuando se ha tratado de desnaturalizar el modelo a través de reformas legales: así ocurrió con la LOAPA y, muy especialmente, es lo que se ha producido cuando los partidos nacionalistas (en un primer momento no abiertamente independentistas) elevaron sus exigencias hasta llevar la descentralización a niveles que superan abiertamente los límites constitucionales. Su origen fue, como se ha apuntado, el Plan Ibarretxe y el proceso estatutario desarrollado entre 2004-2005 ${ }^{80}$, el cual dio pie a una crisis que se ha ido envileciendo con las demandas ya claramente independentistas de ciertos partidos y la insurgencia final de las autoridades catalanas en 2017.

Por lo que, llegados a este punto, cabe reconocer con Rubio Llorente que «[e]l Estado de las Autonomías ha llegado a un estadio que obliga a reflexionar sobre su racionalidad propia y en especial so-

76 REY, F., «Los enemigos de la Constitución», El País, 11/12/2017: https://elpais. com/elpais/2017/12/06/opinion/1512578805_563110.html

77 Así, por ejemplo, RUBIO LLORENTE, F., «Rigidez y rigor mortis», ob. cit., reconoce entre como un buen fruto la generalización del sistema autonómico; pero cuestiona la «maraña legislativa inextricable» y la «administración cara y poco eficaz» a la que ha dado lugar.

${ }^{78}$ En este sentido véase la exposición que realiza MUÑOZ MACHADO, S., Vieja..., ob. cit., passim, aunque aquí no se suscriba en todos sus términos.

79 DE CARRERAS SERRA, F., "Reformar...», ob. cit., pp. 54 y ss., explica con claridad como el Estado de las autonomías se ha ido deslizando hacia un Estado federal, aunque no se han terminado asimilando plenamente su modo de funcionar y filosofía, hasta el imprevisto "bandazo asimétrico y diferencialista».

${ }^{80}$ Puede verse también la dura crítica que se encuentra en ORTEGA, L., ob. cit., en particular páginas 14-16 y 66-67.

(c) UNED. Revista de Derecho UNED, núm. 23, 2018 
bre la conveniencia de mantener el sistema indefinidamente abierto merced a la operación del principio dispositivo con un significado nuevo ${ }^{81}$. Una realidad ante la que cabría plantear tres opciones ${ }^{82}$, aunque las dos primeras decaen desde el momento en el que implican una ruptura con la actual Constitución que descartamos desde el inicio según se concluyó en el apartado anterior: La primera posibilidad que decaería sería una vuelta a la centralización, algo que hoy por hoy no parece ser una opción viable en la medida que no existe ni una demandada política ni social en este sentido, ni resulta técnicamente recomendable habida cuenta de la complejidad de la gobernanza actual ${ }^{83}$. La segunda alternativa también descartada pasaría por articular una suerte de confederación reconociendo una España plurinacional y dando virtualidad jurídica al derecho de autodeterminación ${ }^{84}$. En este supuesto estaríamos ante una alteración sustancial de nuestra Constitución que obligaría a residenciar la soberanía no en el pueblo español, como hasta ahora, sino en los distintos pueblos de España ${ }^{85}$. Una propuesta a mi juicio descabellada que terminaría desembrando nuestro país y que obvia las enseñanzas básicas que ya quedaran plasmadas en El Federalista cuando se justificó la necesidad de superar la confederación. En un mundo glo-

${ }^{81}$ RUBIO LLORENTE, F., «La titularidad del derecho a la autonomía: nacionalidades y regiones», en AA.VV., Estudios sobre la Constitución española. Homenaje al Profesor Jordi Solé Turá, Cortes Generales, Madrid, 2008, p. 1812.

${ }^{82}$ También distinguen estas tres posibilidades SOLOZÁBAL ECHEVARRÍA, J.J., «Una propuesta de cambio federal», en ID, La reforma federal. España y sus siete espejos, Biblioteca Nueva, Madrid, 2014, p. 20, o RUBIO LLORENTE, F., «Rigidez y rigor mortis», ob. cit.

83 Algún autor llega a calificar esta posibilidad como ilícita por su "significación antidemocrática» SOLOZÁBAL ECHEVARRÍA, J.J., "Una propuesta de cambio federal», ob. cit., p. 20-21, y, en cierto modo, el propio MUÑOZ MACHADO, S., Vieja..., ob. cit., pp. 154 y ss.

${ }^{84}$ En este sentido véase OLIVER ARAUJO, J., "Proyectos de reforma para un modelo territorial agotado», en RUIZ-RICO RUIZ, G. et al. (coords.), Regeneración democrática y reforma constitucional, Tirant lo Blanch, Valencia, 2017, pp. 267-304, quien apuesta por otorgar a Cataluña y al País Vasco un estatuto jurídico específico a modo de Estados-libre asociados. MUÑOZ MACHADO, S., Vieja..., ob. cit., llega a admitir esta posibilidad, aunque la critique, siempre y cuando mediara reforma constitucional. En sentido similar, SOLOZÁBAL ECHEVARRÍA, J.J., «Una propuesta de cambio federal», ob. cit., p. 22. Sobre los límites a esta posibilidad de reforma constitucional, vid. TAJADURA TEJADA, J., «El Pacto social como límite a la reforma del acto constitucional», en ROURA, S. y TAJADURA, J. (dirs.), La reforma constitucional. La organización territorial del Estado, la Unión Europea y la igualdad de género, Biblioteca Nueva, Madrid, 2005, pp. 365-400.

85 PÉREZ ROYO, J., La reforma constitucional inviable, ob. cit., pp. 13-14, describe como la cuestión sobre donde residenciar el poder resulta clave y reconoce que si en una sociedad «se pone en cuestión el lugar de residenciación del poder, deja de haber respuesta policía jurídicamente ordenada para la convivencia», como ocurrió con la Guerra Civil en los EE.UU. 
balizado como el actual este paso atrás sería un suicidio. Tanto que, en mi humilde opinión, si hubiera que plantear en algún momento cambiar la residenciación del poder soberano ello sólo debería darse para culminar el proceso de integración europea, actualmente in status nascendi, con el reconocimiento de la soberanía del pueblo europeo. En tercer lugar, la alternativa que encuentra mayor acogida actualmente y que sería la única que encajaría en la Constitución de 1978 sin dañar sus pilares implicaría avanzar en una federalización de nuestro modelo territorial. No se trataría de copiar otros mode$\operatorname{los}^{86}$, por mucho que el alemán sea una referencia clara ${ }^{87}$, sino de introducir mecanismos y técnicas propias del federalismo para adecuarlas a nuestra realidad territorial ${ }^{88}$.

${ }^{86}$ En este punto se ha mostrado muy contundente FERNÁNDEZ RODRÍGUEZ, T-R., «Una reforma necesaria, pero limitada», $A B C, 3 / 12 / 2017$, para quien «Resolver estos problemas no es difícil en absoluto, porque no hay que inventar nada. Sólo hay que copiar la Grundgesetz donde todo eso está escrito y experimentado, lo que no debería suscitar objeciones por parte de nuestros federalistas, ya que el federalismo alemán es el más importante y el más acreditado de Europa y no está tan lejos de nuestros hábitos y de nuestra cultura como el norteamericano».

87 Sobre el federalismo alemán y sus más recientes reformas, vid. de ARROYO GIL, A., "¿El orden federal alemán...», ob. cit.; ID., La reforma constitucional del federalismo alemán, Generalidad de Cataluña. Instituto de Estudios Autonómicos, Barcelona, 2009; ID., "La reforma constitucional de 2009 de las relaciones financieras entre la Federación y los Länder en la República Federal de Alemania», $R E A F$, n. 10, 2010, p. 40-71; ID., "El federalismo alemán», en TAJADURA, J. DE MIGUEL BÁRCENA, J. (eds.), Federalismos del siglo XXI, CEPC, Madrid, 2014, pp. 203-264.; CABELLOS ESPIÉRREZ, M.A., "Evolución y características actuales del federalismo alemán», en SOLOZÁBAL ECHEVARRÍA, J.J. (ed.), La reforma federal. España y sus siete espejos, Biblioteca Nueva, Madrid, 2014, pp. 159-202; SCHEIDER, H.-P., «El nuevo Estado federal alemán. La reforma del federalismo I y su implementación", Teoría y Realidad Constitucional, n. 34, 2014, pp. 99-128; GARCÍA MORALES, M.J., «Investigación y federalismo: la reforma de la Ley Fundamental de Bonn de 2014, ¿qué cambia?», Teoría y Realidad Constitucional, n. 28, 2016, pp. 305-338; y CORDERO GONZÁLEZ, E.M., "La reforma de la constitución financiera alemana. En particular, el nuevo límite al endeudamiento de la Federación y los Länder», Teoría y Realidad Constitucional, n. 29, 2012, pp. 289-234.

88 Así lo expresa ARROYO GIL, A., "¿El orden federal alemán...», ob. cit., p. 373-374. En este sentido, son una mayoría los autores que se muestran favorables a "federalizar» nuestro Estado autonómico: cfr. ORTEGA, L., ob. cit., pp. 2850; AA.VV., Ideas para una reforma de la Constitución, 2017; AJA FERNÁNDEZ, E., "La encrucijada constitucional», Claves de razón práctica, n. 241, 2015, pp. 1827; RUBIO LLORENTE, F., «Defectos de forma», ob. cit., pp. 148 y ss.; SOLOZÁBAL ECHEVARRÍA, J.J., "Una propuesta de cambio federal», ob. cit., pp. 20 y ss.; DE CARRERAS SERRA, F., "Reformar...», ob. cit.; TAJADURA TEJADA, J., "La constitucionalización del mapa autonómico: una reforma necesaria pero insuficiente», en ROURA, S. y TAJADURA, J. (dirs.), La reforma constitucional. La organización territorial del Estado, la Unión Europea y la igualdad de género, Biblioteca Nueva, Madrid, 2005, pp. 281-336; o GARCÍA ROCA, J. (ed.), Pautas..., ob. cit., pp. 99 y ss. A nivel político, el PSOE apostó por ello claramente en su Declaración

(C) UNED. Revista de Derecho UNED, núm. 23, 2018 
Tomando esta última opción como referencia, aparece entonces un nudo gordiano ${ }^{89}$ que exige ser desecho políticamente, aunque luego deba revestirse jurídicamente la solución, y que puede desglosarse en el entrelazamiento de cuatro cuestiones clave: $1{ }^{\circ}$ ) Cerrar (o estabilizar) el modelo territorial ${ }^{90}$, superando el principio dispositivo y adoptando la consiguiente decisión sobre la simetría o no entre las Autonomías; $2^{\circ}$ ) Clarificar el reparto competencial. $3 .^{\circ}$ ) Desarrollar mecanismos de integración y cooperación interterritorial, especialmente reconsiderando la configuración del Senado. $4 .^{\circ}$ ) Fijar las bases de la financiación autonómica.

En relación con la primera de ellas - cómo cerrar el sistema autonómico-, cabe reconocer que probablemente en él se encuentre la cuestión más compleja políticamente de la reforma. Un melón que hay que atreverse a abrir para tratar de lograr una respuesta más o menos definitiva en la Constitución ${ }^{91}$. Tal y como expresaba Rubio Llorente, «[s]i la puerta no se puede cerrar por entero, abría al menos entornarla ${ }^{92}$. Para lo cual creo que hay que afrontar una cuestión principal y otras tantas en cierto modo accesorias.

El problema nuclear se centra en la necesidad de adoptar «un acuerdo nítido y firme sobre la gran cuestión de la homogeneidad o heterogeneidad de la división territorial del poder, de la igualdad o desigualdad en el ámbito de poder de las distintas Comunidades

de Granada. Un nuevo pacto territorial: la España de todos (2013), aunque en su Declaración de Barcelona. Por el catalanismo y la España federal (2017), muestra una deriva con claras preferencias hacia las asimetrías. También el Programa electoral de Ciudadanos ha planteado consolidar el Estado autonómico con una cierta visión federal. Podemos no queda claro si apuesta por un modelo federal o confederal y el PP no parece plantear una alternativa de reforma constitucional en este punto.

${ }^{89}$ RUBIO LLORENTE, F., "Defectos de forma», ob. cit., p. 163 se refiere al «nudo gordiano del constitucionalismo» para recoger los problemas relacionados con la Constitución territorial y su apertura.

90 Más que de «cerrar» el modelo podría ser más adecuado referirse a «estabilizarlo», como hace DE CARRERAS SERRA, F., «Reformar...», ob. cit., p. 90, ya que se trataría de «configurar un marco estable del desarrollo autonómico que fije los límites de la organización y el funcionamiento de las instituciones de las comunidades y, sobre todo, el alcance de sus competencias».

${ }_{91}$ RUBIO LLORENTE, F., «Rigidez y apertura», ob. cit., p. 39. En sentido similar, cfr. RUBIO LLORENTE, F., «Defectos de forma», ob. cit.: pp. 160 y ss. En todos estos trabajos el profesor Rubio Llorente muestra su convicción acerca de la necesidad de afrontar la reforma constitucional para cerrar el modelo autonómico en la Constitución. Son muchos los autores que comparten esta visión y, en general, todos los que apuestan por la evolución federal y que han sido reseñados anteriormente.

92 RUBIO LLORENTE, F., «Rigidez y apertura», ob. cit., p. 39. 
Autónomas» ${ }^{93}$. Pues bien, sin pretender aquí dar una solución definitiva $^{94}$, al menos sí que creo que puede ser conveniente realizar algunas consideraciones para perfilar el debate. De esta suerte, lo primero que ha de tenerse en cuenta es que en nuestro entorno se han dado respuestas desiguales a la homogeneidad o heterogeneidad territorial en los Estados federales. Entre otros, pueden contraponerse el federalismo simétrico alemán o austriaco, con el asimétrico belga y en cierto modo el canadiense ${ }^{95}$. Por nuestra parte, la solución que adoptó la Constitución española de 1978, distinguiendo entre «nacionalidades y regiones», permitiendo distintas vías de acceso a la autonomía y posibilitando su desarrollo heterogéneo, así como reconociendo una serie de hechos diferenciales, puede convenirse que no ha resultado satisfactoria ${ }^{96}$ y exige su reconsideración, según lo dicho.

Actualmente, un sector doctrinal, para dar satisfacción a las exigencias «diferencialistas» que crecen en determinados territorios, plantea la conveniencia de reconocer la diversidad nacional y la asimetría de Cataluña, País Vasco y alguna otra Comunidad Autónoma ${ }^{97}$. Aquí entrarían en juego los llamados "hechos diferenciales ${ }^{98}$, que podrían ser precisados y desarrollados consti-

93 RUBIO LLORENTE, F., «Rigidez y apertura», ob. cit., p. 39. Sobre la lucha por la igualdad y la defensa de la diferencia, véase también, de este mismo autor, RUBIO LLORENTE, F., «La titularidad del derecho a la autonomía..., ob. cit., pp. 1809 y ss.; y RUBIO LLORENTE, F., «Defectos de forma», ob. cit., pp. 160 y ss.

${ }_{94}$ Hay que ser conscientes de que, según se expresaba en el Informe del Consejo de Estado sobre modificaciones de la Constitución española (febrero, 2006): «El abandono del principio dispositivo, poniendo término a la apertura del sistema, es, sin embargo, una tarea complejo que no puede resolverse con fórmulas simplistas» (p. 144).

${ }_{95}$ Para una visión comparada de los distintos sistemas federales, véanse SOLOZÁBAL ECHEVARRÍA, J.J. (ed.), La reforma federal. España y sus siete espejos, Biblioteca Nueva, Madrid, 2014, y TAJADURA, J. y DE MIGUEL BÁRCENA, J. (eds.), Federalismos del siglo XXI, CEPC, Madrid, 2014.

${ }^{6}$ Cfr. RUBIO LLORENTE, F., «La titularidad del derecho a la autonomía..., ob. cit., pp. 1809 y ss.

97 Con una clara apuesta a favor de un federalismo asimétrico en nuestro país sobre la base del reconocimiento de hechos diferenciales, vid. SEIJAS VILLADANGOS, M.E., «El federalismo y nuestro futuro» en AA.VV., Estudios sobre la Constitución española. Homenaje al Profesor Jordi Solé Turá, Cortes Generales, Madrid, 2008, pp. 1815 y ss. De forma sintética también pueden verse las propuestas que recoge el Informe para una reforma de la Constitución en su apartado IV sobre «las reformas en relación a Cataluña». Desde la perspectiva política, véase PSOE: Declaración de Barcelona. Por el catalanismo y la España federal (2017).

${ }_{98}$ Entre los mismos se incluirían fundamentalmente la organización interna de determinados territorios; las lenguas cooficiales; el Derecho civil, foral o especial; y los regímenes fiscales especiales. Con un análisis más detallado, cfr. ARBÓS MARÍN, X., "Hecho diferencial, hecho referencial. La política en la Constitución», en AA.VV., Estudios sobre la Constitución española. Homenaje al Profesor Jordi Solé Turá, Cortes Generales, Madrid, 2008, pp. 1543 y ss. 
tucionalmente. Incluso, se llega a plantear reconocer el carácter nacional de estos territorios particulares y a España como «nación de naciones ${ }^{99}$.

Ocurre que, si nos queremos centrar en tales peculiaridades territoriales, considero que acertaba Muñoz Machado cuando señalaba que todas las Comunidades Autónomas tienen particularidades geográficas, culturales, sociales, históricas, etc. Por ello, cuando se habla de hechos diferenciales, "[l]o importante no son tales hechos, su identificación y delimitación, sino su conversión en potestades, es decir su reconocimiento en la Constitución, de modo que las Comunidades Autónomas puedan diferenciarse entre sí por los poderes políticos y administrativos que tienen atribuidos y la forma en que se relacionan con el Estado» ${ }^{100}$. Así vistos, adquieren pleno sentido las cautelas que se recogen en Ideas para una reforma de la Constitución: «resulta importante que los tratamientos diferenciados puedan sustentarse en justificaciones objetivas». No basta, por tanto, con asumir acríticamente las instituciones o las particularidades que vienen del pasado, sino que habrá que valorar políticamente en qué medida tiene sentido que éstas se mantengan, sobre todo si las mismas afectan a otros principios constitucionales (igualdad entre los españoles, equidad en la distribución de las cargas fiscales, solidaridad interterritorial, libre circulación, etc. $)^{101}$. No en vano sostuvo García Pelayo cuando iba a ser aprobada la Constitución que los derechos históricos reconocidos por ésta representan «la pretensión de sustituir la legitimidad racional por la legitimidad tradicional», algo

99 El mismo RUBIO LLORENTE, F., «Rigidez y rigor mortis», ob. cit., llegaba a plantear la necesidad de adecuar la Constitución a la «nación de naciones» que es España.

100 MUÑOZ MACHADO, S., Informe..., ob. cit., p. 71.

101 Uno de los mejores ejemplos podría ser el del cupo o concierto vasco y navarro. Comparto con MUÑOZ MACHADO, S., Informe..., ob. cit., p. 93 que «[e]1 modelo basado en el concierto, justificado en la Constitución sólo por razones históricas que atañen a concretos territorios, tiene una estructura tan simple como inadecuada para los Estados complejos de nuestro tiempo». Por ello, no parece descabellado desear que se abra un debate sobre la conveniencia de que este sistema se mantenga en la Constitución, más aún cuando éste supone una contradicción con el principio de equitativo reparto de las cargas públicas y de la financiación así como con el ideal de integración fiscal a nivel europeo. También puede ser conveniente plantear la extensión de los Derechos forales, sobre todo cuando éstos se están llevando al extremo de invadir aspectos sensibles como la regulación de las obligaciones y contratos que de manera tan directa afectan a la unidad de mercado y a las relaciones económicas entre los ciudadanos. Incluso, en relación con las lenguas resulta igualmente necesario una intervención clarificadora, no sé si constitucional o puede que baste legislativa, para evitar los constantes conflictos y discriminaciones lingüísticas. Menos problemática resulta a mi juicio la cuestión de las peculiaridades en la organización interna de los territorios forales o insulares. 
que colisiona con las tendencias «racionalistas y progresistas» que fundan el constitucionalismo moderno ${ }^{102}$.

De igual forma, cuando se plantea reconocer el carácter plurinacional de España o se discute sobre la distinción entre «nacionalidades y regiones ${ }^{103}$, al final lo relevante es en qué medida ello afecta al orden jurídico-constitucional ${ }^{104}$. Si se trata de un puro nominalismo romántico, entonces su discusión jurídica me parece estéril; pero si detrás de ello lo que se pretende conseguir es un derecho de autodeterminación o romper con la soberanía del pueblo español para residenciarla en «los pueblos, regiones, comunidades, países y naciones que conforman España» ${ }^{105}$, en tal caso tendría que remitirme a las críticas formuladas anteriormente a la posibilidad de sustituir la Constitución de 1978 por una confederal. Aún más, a aquellos que ven «la renovación democrática» de nuestro marco constitucional en un proceso que sume la voluntad del conjunto del pueblo español con la voluntad de las variopintas comunidades territoriales que conforman España ${ }^{106}$, creo que sería bueno recordarles la jurisprudencia del Tribunal Constitucional español que, asumiendo los postulados básicos del liberalismo democrático, ha concluido: «La Constitución no es el resultado de un pacto entre instancias territoriales históricas que conserven unos derechos anteriores a la Constitución y superiores a ellas, sino una norma del poder constituyente que se impone con fuerza vinculante general en su ámbito, sin que queden fuera de ella situaciones «históricas» anteriores» ${ }^{107}$.

Es por ello que, a mi entender, ante la disyuntiva homogeneidadheterogeneidad, debe apostarse por aquella, sin negar una cierta eficacia a los hechos diferenciales en aquello que resulten razonables y justificados. Se trata de evitar así que la cuestión territorial se mantenga en permanente discusión y sometida a continuas presiones centrífu-

102 GARCÍA PELAYO, M., «El proyecto constitucional y los 'derechos históricos'», El País, 24/09/1978. Texto accesible en: https://elpais.com/diario/1978/09/24/ espana/275436006_850215.html ob. cit.

${ }^{103}$ Cfr. RUBIO LLORENTE, F., «La titularidad del derecho a la autonomía...»,

${ }^{104}$ Cfr. SOLOZÁBAL ECHEVARRÍA, J.J., "Una propuesta de cambio federal», ob. cit., pp. 25 y ss. A este respecto el autor plantea una interesante opción que sería remitir estas cuestiones identitarias de tipo simbólico a los estatutos de autonomía. Algo desde luego menos drástico que incluirlos en la Constitución.

105 BESCANSA, C., Ideas para el debate: Tres propuestas de cambio constitucional para hacer frente a la crisis territorial, 21/11/2017.

106 Ibidem.

107 La primera fue la STC 76/1988, de 26 de abril, FJ. 3. ${ }^{\circ}$, aunque posteriormente ha sido reiterada en numerosas ocasiones.

(C) UNED. Revista de Derecho UNED, núm. 23, 2018 
gas $^{108}$. Una decisión que tendrá costes políticos pero que debe asumirse para que pueda producirse una reforma constitucional ${ }^{109}$.

Una vez que se haya afrontado esta cuestión capital, decía que surgen otras que tendrían un carácter accesorio, a mi entender: si es conveniente mencionar (o no) las Comunidades Autónomas en la Constitución ${ }^{110}$; la posibilidad de incluir la calificación "federal»" ${ }^{111}$; cambiar el derecho a la autonomía por el principio autonómico ${ }^{112}$; replantear la naturaleza de los Estatutos de Autonomía para que, en su caso, quedaran como normas institucionales básicas de una Comunidad sin vehiculizarse como leyes orgánicas ${ }^{113}$; incluir en la Constitución determinados principios para vertebrar el funcionamiento del modelo (principio de lealtad federal, de igualdad entre las CCAA...); suprimir el derecho materialmente transitorio de la Constitución en relación con las vías de acceso y prever mecanismos de modificación de los límites autonómi$\cos ^{114}$; o suprimir la Disposición Transitoria 4. ${ }^{\mathrm{a}}$ referida a Navarra.

108 Así, reconoce BLANCO VALDÉS, R., «¿Por qué la federalización de España...», ob. cit., p. 426, que en España "cuanto más se ha ido descentralizado, más se ha ido incrementando la presión centrífuga». Y, como expresaba RUBIO LLORENTE, F., «Rigidez y apertura», ob. cit., p. 38, lo cierto es que prolongar en el tiempo el carácter abierto de la Constitución no es bueno "y hace vivir en un proceso constituyente permanente». Así lo reconoce también TORRES DEL MORAL, A., «Estado autonómico...», ob. cit. p. 80; y el CONSEJO DE ESTADO: Informe sobre modificaciones..., ob. cit., p. 143.

109 RUBIO LLORENTE, F., "Rigidez y apertura», ob. cit., p. 39 consideraba, creo que acertadamente, que "[l]a dificultad hasta ahora insalvable para reformar nuestra Constitución viene exclusivamente de la impotencia de nuestros representantes de hoy para ir más allá del compromiso dilatorio con el que los constituyentes de 1978 (como antes los de 1931) salieron del paso para dar satisfacción al particularismo de las que Ortega llamaba "regiones ariscas"». Y concluía: "por eso creo necesaria la reforma constitucional en este punto. Y [...] sólo con ella, sólo cerrando esta puerta, se abrirán las que hacen posible acometer otras reformas (p. 38).

110 Sobre las distintas posibilidades de mencionar las CCAA en la Constitución, véase el estudio realizado por el CONSEJO DE ESTADO: Informe sobre modificaciones..., ob. cit., pp. 146.

${ }_{111}$ Comparto con el informe Ideas para una reforma de la Constitución que no hay que darle excesiva importancia al término con el que se califique al Estado, sino que lo importante es reformar el modelo territorial asumiendo las técnicas del federalismo. No obstante, algún autor ha considerado útil la posibilidad de incluirlo: así, SOLOZÁBAL ECHEVARRÍA, J.J., «Una propuesta de cambio federal», ob. cit., p. 25.

112 DE CARRERAS SERRA, F., "Reformar...», ob. cit., pp. 95 y ss.

113 Favorable a esta opción se muestra Ideas para una reforma de la Constitución. En contra, vid. SOLOZÁBAL ECHEVARRÍA, J.J., "Una propuesta de cambio federal», ob. cit., p. 66. GARCÍA ROCA, J. (ed.), Pautas..., ob. cit., pp. 112-113 reconoce que sobre este punto no hubo consenso en el grupo de trabajo.

114 Cfr. BILBAO UBILLOS, J.M., «La modificación del mapa autonómico: creación de nuevas Comunidades autónomas y alteración de los límites territoriales existentes», en AA.VV., Estudios sobre la Constitución española. Homenaje al Profesor Jordi Solé Turá, Cortes Generales, Madrid, 2008, pp. 1563-1597. 
En segundo lugar, otra de las cuestiones que adquieren sustantividad propia es la referida a la distribución competencial. La falta de claridad con la que las mismas se habían previsto en la Constitución había convertido nuestro modelo territorial en un «Estado jurisdiccional autonómico» ${ }^{115}$, altamente conflictivo. Afrontar esta cuestión desde el punto de vista jurídico no reviste gran complejidad: se trataría, por un lado, de definir las distintas categorías competenciales y la forma de recogerlas (una o varias listas), y, por otro, fijar una cláusula residual y matizar los principios ordenadores (prevalencia, supletoriedad... $)^{116}$. Después, lo verdaderamente complejo es la negociación política sobre el reparto concreto de las competencias. Una tarea que deberá orientarse atendiendo a criterios de eficiencia (no de pura oportunidad política ni estrictamente jurídicos) en el ejercicio de las potestades en cuestión y tengan en cuenta el principio de subsidiariedad.

En tercer lugar, cabe plantear la necesidad de desarrollar unos mecanismos adecuados de integración y de cooperación interterritorial ${ }^{117}$; lo que exige fundamentalmente replantear la configuración del Senado ${ }^{118}$ como cámara territorial» $\mathrm{y}$, al mismo tiempo, cámara «de

115 SOLOZÁBAL ECHEVARRÍA, J.J., «Una propuesta de cambio federal», ob. cit., p. 40.

${ }_{116}$ Por ejemplo, en Ideas para una reforma de la Constitución se apuesta por asumir la técnica clásica del federalismo por la cual la Constitución fija las competencias del Estado y el resto serían de las Comunidades Autónomas, sin perjuicio de ciertas cláusulas como la de prevalencia. Sobre la posibilidad de establecer una forma federal de atribuir competencias, véanse también DE CARRERAS SERRA, F., «Reformar...», ob. cit., p. 101 y ss.; ID., .., «Una posible reforma constitucional del sistema de distribución de competencias», en AA.VV., La Constitución política de España, CEPC, Madrid, 2016, pp. 457-476; ARROYO GIL, A., «¿El orden federal alemán...», ob. cit., pp. 394 y ss.; MUÑOZ MACHADO, S., Informe..., ob. cit., pp. 99 y ss.; GARCÍA ROCA, J. (ed.), Pautas..., ob. cit., pp. 105 y ss.

117 Cfr. SOLOZÁBAL ECHEVARRÍA, J.J., «Una propuesta de cambio federal», ob. cit.. sobre técnicas de cooperación e integración.

118 Desde los años noventa, como se vio, la cuestión de la reforma del Senado ha revestido un notable interés académico que ha dado lugar a interesantes trabajos. Así, entre otros muchos, podrían citarse AA.VV., La reforma del Senado, CEPCSenado, Madrid, 1994; AA.VV., El Senado, Cámara de representación territorial, Tecnos, Madrid, 1996; GARRORENA MORALES, A., «Una propuesta para la reforma constitucional del Senado», Revista de las Cortes Generales, n. 34, 1995; FERNÁNDEZ SEGADO, F., "Reflexiones en torno a la reforma constitucional del Senado», Revista de Derecho Político, n. 42, 1996; o LÓPEZ GARRIDO, D., «Hacia un nuevo Senado: propuesta de reforma constitucional», Revista de las Cortes Generales, n. 33, 1994. Más recientemente pueden verse ROURA GÓMEZ, S., «La reforma constitucional del Senado en la VIII Legislatura», en ROURA, S. y TAJADURA, J. (dirs.), La reforma constitucional. La organización territorial del Estado, la Unión Europea y la igualdad de género, Biblioteca Nueva, Madrid, 2005, pp. 337-364; AA.VV., Estudios sobre la Constitución española. Homenaje al Profesor Jordi Solé Turá, Cortes Gene- 
representación» ${ }^{119}$. A este respecto, las principales cuestiones a resolver serían, en relación con su composición: ¿Senado parlamentario o tipo consejo ${ }^{120}$ ? Y, en consecuencia, ¿cuál sería el número y forma de elección de los senadores ${ }^{121}$ ? En cuanto a sus funciones: ¿Parlamentarismo desequilibrado? ¿Cuáles habrían de ser las competencias del Senado y qué papel debe jugar en cada procedimiento (legislativo, control al gobierno.... $)^{122}$ ? Asimismo, puede contemplarse la oportunidad de prever en la Constitución mecanismos de coordinación como la Conferencia de Presidentes Autonómicos o las conferencias sectoriales, entre otros posibles organismos técnicos o políti-

rales, Madrid, 2008, pp. 281 y ss.; MORALES ARROYO, J.M., «La segunda cámara como elemento necesario en la arquitectura constitucional», en FREIXES SANJUÁN, T. y GAVARA DE CARA, J.C. (coords.), Repensar la constitución. Ideas para una reforma de la Constitución de 1978: reforma y comunicación dialógica. Parte primera, CEPC-BOE, Madrid, 2016, pp. 131-150; GACÍA ROCA, J. y ALBERTI, E. (coords.), Treinta años de Constitución, Tirant lo Blanch, Valencia, 2010, pp. 39 y ss; especialmente GARRORENA MORALES, A., "Nuevas condiciones desde las que replantear el cometido de la doctrina respecto de la reforma del Senado», ob. cit., pp. 39 y ss. Y, por supuesto, CONSEJO DE ESTADO: Informe sobre modificaciones..., ob. cit., p. 231 y ss.

${ }^{119}$ En este punto creo que son especialmente importantes las aportaciones del CONSEJO DE ESTADO: Informe sobre modificaciones..., ob. cit., pp. 321 y ss., en el cual el Alto órgano consultivo delineaba con precisión las consecuencias de reconocer al Senado como cámara de representación territorial: «De representación territorial en un sentido más estricto cabe hablar solo cuando la representación se articula de manera tal que a través de ella adquieren voz propia las diversas partes territorialmente diferenciadas de la comunidad política única, de la Nación. Los `territorios` no son ya simples circunscripciones electorales, sino la delimitación espacial de conjuntos políticos concretos que se incorporan en cuanto tales al proceso de formación de la voluntad del Estado» (p. 233). Ello conllevaría que un Senado con una organización gubernamental tipo Consejo (modelo alemán) no pueda concebirse como cámara de representación política en sentido estricto.

120 Como se acaba de señalar en la nota anterior, véanse especialmente las consideraciones CONSEJO DE ESTADO: Informe sobre modificaciones..., ob. cit., pp. 321 y ss.; y las posibilidades que esboza GARCÍA ROCA, J. (ed.), Pautas..., ob. cit., pp. 57 y ss. En la doctrina no hay una posición clara favorable a uno u otro modelo. Así, apuestan por su carácter parlamentario, entre los trabajos más recientes, SOLOZÁBAL ECHEVARRÍA, J.J., «Una propuesta de cambio federal», ob. cit., pp. 58 y ss., y su trabajo "Nuevas perspectivas sobre la reforma del Senado», en AA.VV., Estudios sobre la Constitución española. Homenaje al Profesor Jordi Solé Turá, Cortes Generales, Madrid, 2008, pp. 903 y ss. Por otro lado, prefieren la composición como Consejo, entre otros, AA.VV., Ideas para una reforma de la Constitución, 2017, aunque abierto a otras posibilidades; y DE CARRERAS SERRA, F., «Reformar...», ob. cit.: p. 110.

${ }^{121}$ A este respecto véanse las diversas fórmulas que estudia el CONSEJO DE ESTADO: Informe sobre modificaciones..., ob. cit., pp. 237 y ss.

122 Cfr CONSEJO DE ESTADO: Informe sobre modificaciones..., ob. cit., pp. 244. En doctrina, entre otros muchos, vid. SOLOZÁBAL ECHEVARRÍA, J.J., «Una propuesta de cambio federal», ob. cit., pp. 58 y ss.; e ID., «Nuevas perspectivas...», ob. cit., pp. 903 y ss. 
$\cos ^{123}$, y podría ser interesante revisar la regulación constitucional de los convenios entre Comunidades Autónomas.

El último de los grandes frentes abiertos sobre el Estado autonómico sería la cuestión de la financiación. Como se explica en Ideas para la reforma constitucional: «La Constitución puede incluir normas fundamentales del sistema de financiación, con aproximación a la atribución de recursos según las capacidades de ingreso y criterios de solidaridad, incluyendo los principios de igualdad social y de ordinalidad (arts. 156, 147 y $158 \mathrm{CE}$ ), así como garantizar la participación de las Comunidades en la concreción de ese modelo» ${ }^{124}$. La Constitución recogería así los «principios básicos» que den una «mayor estabilidad y seguridad al sistema» ${ }^{125}$, los cuales habrían de ser desarrollados por el legislador ${ }^{126}$.

Más allá, también dentro del capítulo de la estructura territorial del poder, quedarían las cuestiones relativas a las provincias y a los municipios. Con respecto a las provincias cabe plantear la conveniencia de su «deconstitucionalización», perdiendo su blindaje constitucional como entes locales. Así, la definición de los entes locales supramunicipales podría realizarse en los Estatutos de Autonomía para que cada Comunidad se estructure según sus necesidades (provincias, veguerías, comarcas... $)^{127}$. Adicionalmente, podría afrontarse la posibilidad de constitucionalizar con mayor detalle el contenido de la autonomía municipal.

Para concluir este ámbito, para atender las demandas territoriales parece que la mejor vía es la de la reforma constitucional,

${ }^{123}$ Cfr. SOLOZÁBAL ECHEVARRÍA, J.J., "Una propuesta de cambio federal», ob. cit., p. 61.

${ }^{124}$ Con un estudio más extenso de la cuestión, cfr. MONTILLA MARCOS, J.A., «La financiación autonómica en la reforma constitucional», en FREIXES SANJUÁN, T. y GAVARA DE CARA, J.C. (coords.), Repensar la constitución. Ideas para una reforma de la Constitución de 1978: reforma y comunicación dialógica. Parte primera, CEPC-BOE, Madrid, 2016, pp. 227-156. También, con propuestas concretas, cfr. GARCÍA ROCA, J. (ed.), Pautas..., ob. cit., pp. 115 y ss.

${ }^{125}$ De forma similar ARROYO GIL, A., "¿El orden federal alemán...», ob. cit., pp. 397-398, apuesta por introducir en la Constitución los principios básicos que han de guiar al legislador sobre financiación autonómica, reconociendo como tales la corresponsabilidad fiscal, la solidaridad interterritorial y el principio de ordinalidad. Desde la perspectiva de introducir reformas legales, pero con indudable impacto.

126 A este respecto, como muestra de que no todo son reformas constitucionales, pueden verse las Propuestas de reforma del sistema de financiación autonómica elaborada por una Comisión de Expertos a propuesta de la Conferencia de Presidentes Autonómicos y que ha sido publicada en julio de 2017. Texto accesible en: http:// www.minhafp.gob.es/Documentacion/Publico/CDI/Sist $\% 20$ Financiacion $\% 20 y \% 20$ Deuda/InformaciónCCAA/Informe_final_Comisión_Reforma_SFA.pdf

127 En este sentido GARCÍA ROCA, J. (ed.), Pautas..., ob. cit., p. 108. 
sobre todo después de los fracasos al haber tratado de atender a las mismas a través de reformas legislativas. Los vínculos constitucionales no son muy severos pero la Constitución no es absolutamente disponible e impone límites que deben respetarse; amén de que, según se ha visto, en buena medida los problemas derivan precisamente de la falta de una decisión constitucional. Es cierto que, a falta de la misma, pudieron servir los grandes pactos autonómicos que lograron dar un cierto orden al desarrollo del Estado de las autonomías. Pero difícilmente esto es posible en el escenario político actual sin reconducirlo a través del procedimiento de reforma constitucional. Una reforma que podría acometerse íntegramente a través del artículo $167 \mathrm{CE}$ y sólo si alguno de los aspectos planteados quisiera trasladarse al Título Preliminar (el reconocimiento de las Comunidades Autónomas, la calificación federal, o el principio de autonomía, por ejemplo), entonces sí que sería necesario acudir al art. $168 \mathrm{CE}$. Fuera de la reforma constitucional quedan muchos otros aspectos que habría que afrontar a través de iniciativas legislativas y de acuerdos políticos en relación con el adecuado y eficiente funcionamiento del modelo territorial $^{128}$.

\section{V.2. La integración europea como fenómeno constitucional}

Tal y como reconocía el Consejo de Estado en su informe de 2006: «Todos los Estados que forman parte de la Unión Europea se encuentran abocados a la difícil tarea de cohonestar dos órdenes jurídico-políticos, estrechamente imbricados, pero no reducidos a unidad» ${ }^{129}$. La integración europea se desvela como un fenómeno constitucional que reclama una recepción en las Constituciones nacionales. Tanto que, por el momento, se puede hablar de que en este punto la Constitución española de 1978 ha experimentado una clara mutación ${ }^{130}$, con la aquiescencia del Tribunal Constitucional que concluyó que no era necesaria la revisión de nuestra Norma Funda-

128 Véanse las interesantes propuestas que en su día realizó MUÑOZ MACHADO, S., Informe..., ob. cit., passim. En este intento de lograr una mayor eficiencia de nuestras administraciones, de gran relevancia es el Informe para la reforma de las Administraciones Públicas elaborado a petición del Gobierno en 2012. Toda la información sobre el mismo se encuentra disponible en: http://www.sefp. minhafp.gob.es/web/areas/reforma_aapp.html

129 CONSEJO DE ESTADO: Informe sobre modificaciones..., ob. cit., p. 49.

${ }_{130}$ Con carácter general en una visión comparada se refiere a ella el CONSEJO DE ESTADO: Informe sobre modificaciones..., ob. cit., p. 75. 
mental para hacerla compatible con el principio de primacía del Derecho de la Unión ${ }^{131}$.

Ello no quita que pueda predicarse la conveniencia de incluir expresamente una regulación constitucional de este fenómeno ${ }^{132}$. El Consejo de Estado proponía a este respecto incorporar en el Preámbulo de la Constitución la voluntad de participar en el proceso de construcción de la Unión Europea ${ }^{133}$ y establecer un precepto referido a la ratificación de los tratados de la UE e incluir alguna cláusula en relación con la integración del Derecho europeo en el sistema de fuentes ${ }^{134}$. Además, se pueden suscitar otras cuestiones como las relaciones Gobierno-Cortes Generales y Estado-CCAA en materias europeas ${ }^{135}$, y las funciones del juez ordinario como juez europeo ${ }^{136}$. La doctrina ha prestado también particular interés a la integración a través de los derechos, incluyendo el impacto derivado del Consejo de Europa ${ }^{137}$.

${ }^{131}$ DTC 1/2004, de 13 de diciembre. El Consejo de Estado, sin embargo, se había pronunciado en contra de tal compatibilidad en su Dictamen de 21 de octubre de 2004. Con una crítica a la Declaración del Tribunal Constitucional, me remito a mi trabajo TERUEL LOZANO, G.M., «El Tribunal Constitucional ante el principio de primacía del Derecho comunitario", Anales de Derecho. Universidad de Murcia, n. 24, 2006, pp. 319-352.

132 Como explica DÍAZ REVORIO, F.J., «Perspectivas de la reforma...», ob. cit., p. 25, la reforma constitucional en este punto resulta altamente conveniente a pesar de que el Tribunal Constitucional haya admitido el principio de primacía. Sobre esta cuestión pueden verse, entre otros, GARCÍA ROCA, J. (ed.), Pautas..., ob. cit., pp. 29 y ss.; y GARCÍA GESTOSO, N., «El proceso de integración europea y la Constitución Española de 1978: reflexiones sobre la necesidad o conveniencia de reformar nuestra Constitución para adaptarla a la dinámica europea», en ROURA, S. y TAJADURA, J. (dirs.), La reforma constitucional. La organización territorial del Estado, la Unión Europea y la igualdad de género, Biblioteca Nueva, Madrid, 2005, pp. 401-478.

133 En GARCÍA ROCA, J. (ed.), Pautas..., ob. cit., pp. 29 y ss. se plantea también la posibilidad de mencionar los vínculos con Iberoamérica.

${ }^{134}$ CONSEJO DE ESTADO: Informe sobre modificaciones..., ob. cit., pp. 100 y ss.

135 Cfr. BALAGUER CALLEJÓN, F., «La integración del pluralismo territorial infraestatal en los procesos normativos de la Unión Europea», en AA.VV., La Constitución política de España, CEPC, Madrid, 2016, pp. 401 y ss.

136 CONSEJO DE ESTADO: Informe sobre modificaciones..., ob. cit., pp. 107 y ss.

137 En especial, cfr. GARCÍA ROCA, J. (ed.), Pautas..., ob. cit., pp. 29 y ss. También pueden verse JIMENA QUESADA, L., «La actualización de la Constitución Española ante la Carta de derechos fundamentales de la Unión Europea», en ROURA, S. y TAJADURA, J. (dirs.), La reforma constitucional. La organización territorial del Estado, la Unión Europea y la igualdad de género, Biblioteca Nueva, Madrid, 2005, pp. 479-523; y FREIXES, T., «Los derechos fundamentales: el enfoque multinivel», en FREIXES SANJUÁN, T. y GAVARA DE CARA, J.C. (coords.), Repensar la constitución. Ideas para una reforma de la Constitución de 1978: reforma y comunicación dialógica. Parte primera, CEPC-BOE, Madrid, 2016, pp. 23-38. 
La reforma constitucional en este punto podría desarrollarse vía artículo 167 de la Constitución.

\section{V.3. La Corona y la igualdad en la sucesión}

Una vez que el Rey Felipe VI sólo ha tenido hijas se ha remitido la intensidad de la necesidad de reformar la sucesión a la Corona para corregir la actual discriminación a favor del varón. Ahora bien, ello no quita que exista un amplio consenso en cuanto a la revisión de esta regla constitucional, algo que antes o después deberá acometerse. Una intervención que, en este caso sí, sólo puede realizarse por el procedimiento especialmente agravado del art. $168 \mathrm{CE}^{138}$. Sin caer ahora en planteamientos más extremos como sería la supresión de la forma monárquica de la Jefatura del Estado, los cuales nos llevarían a tener que emprender una reforma estructural de la Constitución excesiva e innecesariamente costosa, según lo ya dicho, sí que cabría plantear otras mejoras en la regulación constitucional de la Corona: replantear la extensión de la cláusula de inviolabilidad e irresponsabilidad absoluta del Rey; contemplar la posición del Príncipe de Asturias y sus títulos; y algunas cuestiones relacionadas con el matrimonio y la sucesión o las funciones del monarca y su refrendo ${ }^{139}$. No obstante, ninguna de ellas parece responder a una exigencia socio-política imperiosa.

\section{V.4. Regeneración democrática ante la crisis de representatividad}

Se ha podido ver cómo uno de los «defectos de forma» ${ }^{140}$ de nuestra Constitución o, por mejor decir, del desarrollo que ésta ha tenido a lo largo de estos cuarenta años de democracia, se relaciona con el sistema político y, dentro del mismo, con el sistema de partidos y con el sistema electoral. A ello cabe añadir las reivindicaciones que exigen dar más participación a los ciudadanos en un momento de seria crisis de nuestra democracia representativa. Se destacaban,

${ }^{138}$ Cfr. CONSEJO DE ESTADO: Informe sobre modificaciones..., ob. cit., pp. 18 y ss.

139 Cfr. GÓMEZ SÁNCHEZ, Y., «La monarquía parlamentaria en la Constitución de 1978: valoración y propuestas de reforma constitucional», en FREIXES SANJUÁN, T. y GAVARA DE CARA, J.C. (coords.), Repensar la constitución. Ideas para una reforma de la Constitución de 1978: reforma y comunicación dialógica. Parte primera, CEPC-BOE, Madrid, 2016, pp. 73-100. En GARCÍA ROCA, J. (ed.), Pautas..., ob. cit., pp. 67 y ss., se muestran muy cautos en cuanto a la posibilidad de retocar otras cuestiones en la Constitución más allá de la discriminación por razón del sexo en la sucesión a la Corona.

140 RUBIO LLORENTE, F., "Defectos de forma», ob. cit. 
además, dos males que impregnan el sistema: por un lado, el predominio partitocrático; y, por otro lado, el «parlamentarismo enfermizo», en dura expresión de Aragón Reyes ${ }^{141}$.

Ahora bien, por mucho que estas cuestiones podemos reconocerlas como materialmente constitucionales, es en estos ámbitos donde más mejoras se pueden alcanzar mediante reformas legislativas y de los reglamentos parlamentarios ${ }^{142} \mathrm{y}$, por ende, donde menos necesaria resulta la revisión constitucional. La Constitución es bastante abierta en las normas que disciplinan nuestro sistema político y, de hecho, sólo de forma remota se pueden imputar los males que se quieren combatir a una inadecuada regulación constitucional. Es cierto, en cualquier caso, que la revisión de alguna cuestión puntual en la Constitución puede ayudar a avanzar más (por ejemplo, en materia electoral). En tal caso se podría operar a través del art. $167 \mathrm{CE}$, sin que a priori se vean afectadas cuestiones dentro del ámbito del art. $168 \mathrm{CE}$.

A efectos puramente ilustrativos podríamos identificar los siguientes ámbitos de mejoras: 1) Sistema electoral (con dos objetivos fundamentales: mayor proporcionalidad pero garantizando la estabilidad y más libertad de los electores —apertura y desbloqueo de listas- $)^{143}$; 2) Sistema de partidos (democracia interna -obligatoriedad de congresos, discusión sobre primarias...-; modelo de financiación; y mecanismos de prevención y lucha contra la corrupción); 3) Instrumentos de participación ciudadana directa o semi-directa (por un lado, revisión de la iniciativa legislativa popular y del referéndum; pero también reformas para lograr un procedimiento legislativo más abierto y transparente) ${ }^{144}$; 4) Refortalecimiento de la posición del parlamento

141 ARAGÓN REYES, M., Estudios de Derecho Constitucional, CEPC, Madrid, 2013, pp. 699 y ss.

${ }_{142}$ Me remito aquí a mi trabajo TERUEL LOZANO, G.M., «La reforma de los reglamentos parlamentarios como instrumento para la regeneración democrática», Revista administración \& ciudadanía, n. 1, 2017.

${ }^{143}$ De gran interés en este punto es CONSEJO DE ESTADO: Informe sobre las propuestas de modificación del régimen electoral general, 24 de febrero de 2009. Véase también RUBIO LLORENTE, F., "Defectos de forma», ob. cit., pp. 139 y ss; y GARCÍA ROCA, J. (ed.), Pautas..., ob. cit., pp. 45 y ss. Y, entre los trabajos más recientes que se recogen en en RUIZ-RICO RUIZ, G. et al. (coords.), Regeneración democrática y reforma constitucional, Tirant lo Blanch, Valencia, 2017, pp. 127 y ss.

${ }^{144}$ En este punto merece la pena destacar la Proposición de reforma constitucional presentada por la Junta General del Principado de Asturias el 16 de octubre de 2014 para la reforma de los artículos 87.3, 92 y 166 de la Constitución. Igualmente, en relación con la revisión del procedimiento legislativo para lograr un sistema más abierto y transparente, recomiendo especialmente los trabajos de GARCÍA-ESCUDERO MÁRQUEZ, P. (2015), «Regeneración del Parlamento, transparencia y participación ciudadana», Teoría y Realidad Constitucional, n. 36, pp. 171-216 e ID. "Las Cortes Generales: nuevos roles y transformación de funciones», en FREIXES SAN- 
como contrapoder frente a un gobierno de canciller (protagonismo de la oposición en los instrumentos de control al gobierno; refuerzo del parlamentario individual; límites a los decretos-leyes; y medidas de reequilibrio de la posición preeminente del Presidente del Gobierno - posibilidad de investidura colegial, reprobación de ministros e incluso replantear el carácter constructivo de la moción de censura- ${ }^{145}$; y 5) Contrapesos y garantías de independencia de otros órganos constitucionales (composición, elección y funciones del Tribunal Constitucional $^{146}$, Consejo General del Poder Judicial ${ }^{147}$ y del Fiscal General del Estado $^{148}$, y Tribunal de Cuentas ${ }^{149}$ ).

JUÁN, T. y GAVARA DE CARA, J.C. (coords.), Repensar la constitución. Ideas para una reforma de la Constitución de 1978: reforma y comunicación dialógica. Parte primera, CEPC-BOE, Madrid, 2016, pp. 101-130.

${ }^{145}$ De forma general, cfr. RUBIO LLORENTE, F., «Defectos de forma», ob. cit., p. 139; GARCÍA ROCA, J. (ed.), Pautas..., ob. cit., 73 y ss.; y GARCÍA-ESCUDERO MÁRQUEZ, P., «Las Cortes Generales...», ob. cit., pp. 101 y ss.

${ }_{146}$ Sobre la revisión de la regulación del Tribunal Constitucional véanse, con opiniones contrapuestas, (TORRES MURO, I., «Tribunal Constitucional: composición y funciones», en FREIXES SANJUÁN, T. y GAVARA DE CARA, J.C. (coords.), Repensar la constitución. Ideas para una reforma de la Constitución de 1978: reforma y comunicación dialógica. Parte primera, CEPC-BOE, Madrid, 2016, pp. 173-190; poco proclive a ellas en la medida que considera que los problemas que sufre no son causa de las normas sino de la práctica política; y, con propuestas concretas de mejoras, AZPITARTE SÁNCHEZ, M., "Tribunal Constitucional: necesidad y posible reforma», en FREIXES SANJUÁN, T. y GAVARA DE CARA, J.C. (coords.), Repensar la constitución. Ideas para una reforma de la Constitución de 1978: reforma y comunicación dialógica. Parte primera, CEPC-BOE, Madrid, 2016, pp. 191-208, en relación con la composición, elección y mandato de los magistrados constitucionales y también sobre sus funciones. Véase también GARCÍA ROCA, J. (ed.), Pautas..., ob. cit., pp. 91 y ss.

147 Cfr. GARCÍA ROCA, J. (ed.), Pautas..., ob. cit., pp. 85 y ss.; GERPE LANDÍN, M. y CABELLOS ESPIÉRREZ, M.A., «La configuración del poder judicial en la Constitución y su desarrollo posterior: algunos aspectos relevantes», en FREIXES SANJUÁN, T. y GAVARA DE CARA, J.C. (coords.), Repensar la constitución. Ideas para una reforma de la Constitución de 1978: reforma y comunicación dialógica. Parte primera, CEPC-BOE, Madrid, 2016, pp. 209-228; y BALLESTER CARDELL, M., «Reforma constitucional y poder judicial: dos propuestas para el caso español», en RUIZ-RICO RUIZ, G. et al. (coords.), Regeneración democrática y reforma constitucional, Tirant lo Blanch, Valencia, 2017, pp. 53-88.

148 A este respecto, véase la Proposición de Ley de modificación de la Ley 50/1981, de 30 de diciembre, por la que se regula el Estatuto Orgánico del Ministerio Fiscal que fue presentada por el Grupo parlamentario de Ciudadanos el 7 de junio de 2017. No obstante lo cual, precisamente una de las cuestiones que deberían discutirse en un hipotético proceso de reforma constitucional sería la actual posición institucional del Fiscal General del Estado a caballo entre el Poder Judicial y el Gobierno, sobre todo cuando se está planteando la posibilidad de que la Fiscalía asuma la instrucción de los procesos penales. A este respecto, cfr. GARCÍA ROCA, J. (ed.), Pautas..., ob. cit., p. 88.

${ }^{149}$ Cfr. BIGLINO CAMPOS, P., «El control de cuentas: un contenido necesario de la reforma constitucional», en FREIXES SANJUÁN, T. y GAVARA DE CARA, J.C. (coords.), Repensar la constitución. Ideas para una reforma de la Constitución de 1978: reforma y comunicación dialógica. Parte primera, CEPC-BOE, Madrid, 2016, pp. 151-172. 


\section{V.5. Garantía de los derechos constitucionales en momentos de crisis económica y de revolución tecnológica}

Los derechos constitucionales también son un ámbito en el que la flexibilidad de la Constitución permite su evolución sin reclamar su revisión formal. No obstante lo cual, la doctrina ha destacado algunas cuestiones en las podrían introducirse ciertas reformas ${ }^{150}$. En concreto, siguiendo aquí la exposición realizada por el grupo de trabajo coordinado por el profesor García Roca ${ }^{151}$ : reconocer el derecho a la vida privada y familiar en el art. 18.1 CE; contemplar como derechos fundamentales ciertos derechos y principios constitucionales que antes no gozaban de tal condición (así, derecho al matrimonio, derecho a la seguridad social y derecho a la protección de la salud) ${ }^{152}$; eliminar ciertas restricciones en el derecho al sufragio de los extranjeros; revisar la regulación legal de la mayoría de edad y la titularidad del derecho al matrimonio; exigir ley orgánica para la ratificación de los tratados internacionales sobre derechos; abolir la pena de muerte sin excepción; reforzar el mandato de protección de algunos principios rectores (ej. protección del medio ambiente); y suprimir algún precepto obsoleto (ej. prohibición de los tribunales de honor). También podría perfilarse el derecho a la protección de datos y, más en general, desarrollarse el fenómeno de las nuevas tecnologías y su afectación a los derechos fundamentales ${ }^{153}$.

${ }^{150}$ Véase especialmente GARCÍA ROCA, J. (ed.), Pautas..., ob. cit., pp. 27 y ss. También, cfr. GAVARA DE CARA, J.C., «Los derechos fundamentales: valoración y posibles modificaciones», en FREIXES SANJUÁN, T. y GAVARA DE CARA, J.C. (coords.), Repensar la constitución. Ideas para una reforma de la Constitución de 1978: reforma y comunicación dialógica. Parte primera, CEPC-BOE, Madrid, 2016, pp. 39-72.

151 GARCÍA ROCA, J. (ed.), Pautas..., ob. cit., pp. 27 y ss.

152 Para ello, en GARCÍA ROCA, J. (ed.), Pautas..., ob. cit., p. 38, se imponen como condiciones para pasar a ser reconocidos como derechos fundamentales que estos sean reconocidos por el Convenio Europeo y hayan tenido un amplio desarrollo legislativo tras la aprobación de la Constitución que les permite ser considerados como auténticos derechos prestacionales universalmente garantizados. Unas cautelas que parecen acertadas, ya que la garantía de los derechos sociales exige en última instancia recursos económicos y priorizar por tanto necesidades sociales, algo fuera del alcance de los jueces. En este sentido, véanse las críticas de RUBIO LLORENTE, F., «Proceso constituyente...», ob. cit., al intento de blindar constitucionalmente ciertos derechos sociales. Porque, al final, «un derecho "vale lo que valen sus garantías” (GARCÍA ROCA, J. (ed.), Pautas..., ob. cit., p. 38).

${ }^{153}$ Así, por ejemplo, la prohibición de censura previa adquiere nuevas dimensiones cuando se proyecta sobre el ejercicio de ésta a través de Internet. Sobre esta cuestión puede verse mis trabajos TERUEL LOZANO, G.M., "Libertades comunicativas y censura en el entorno tecnológico global», Revista de la Escuela Jacobea de Posgrado [en línea], n. 12, 2017, pp. 75-102; y «Perspectivas de los derechos fundamentales en la sociedad digital», Fundamentos. Cuadernos monográficos de teoría del estado, derecho público e historia constitucional, n. 9, 2016, pp. 215-243. 
Quedaría señalar únicamente que la reforma constitucional en este punto exigiría proceder según el art. 168 de la Constitución en la medida que se vieran afectados los derechos reconocidos en la Sección 1. ${ }^{\mathrm{a}}$ del Capítulo II del Título I de la Constitución.

\section{V.6. La reforma de la reforma}

Por último, uno de los aspectos que por motivos técnicos, y en cierto modo también políticos, podría ser conveniente reformar son los procedimientos de reforma constitucional previstos en el Título $\mathrm{X}$ de la Constitución. Existen, como digo, cuestiones que serían puras mejoras técnicas para superar algunas imprecisiones y defectos del diseño actual ${ }^{154}$; pero también hay un aspecto con importantes connotaciones políticas que ha de ser considerado: la que por muchos es considerada «excesiva» rigidez del artículo $168^{155}$. Un artículo que algunos han llegado a considerar como una «cláusula de intangibilidad encubierta» ${ }^{156}$. De ahí que existan interesantes propuestas tendentes a reformar el mismo e, incluso, a refundirlo en un único procedimiento de reforma ${ }^{157}$.

En tal caso, parece que la opción más adecuada es reformar el artículo 168 recurriendo al procedimiento que el mismo prevé ${ }^{158}$, a

${ }^{154}$ Con carácter general sobre los procedimientos de reforma diseñados por la Constitución española, véanse los trabajos clásicos de DE VEGA, P., ob. cit., pp. 128 y ss.; PÉREZ ROYO, J., La reforma de la Constitución, ob. cit., pp. 127 y ss.; y, más recientemente GARCÍA-ATANCE, M.V., ob. cit., VERA SANTOS, J.M., ob. cit.; GARCÍA-ESCUDERO MÁRQUEZ, P., El procedimiento..., ob. cit.

155 Ya DE VEGA, P., ob. cit., p. 148, acusaba la excesiva rigidez del art. 168, al que consideraba un procedimiento para «evitar» la reforma. En sentido similar destacaba PÉREZ ROYO, J., La reforma de la Constitución, ob. cit., pp. 127 y ss.: «ante la imposibilidad de introducir cláusulas de intangibilidad, como se hubiera deseado..., para impedir de iure el cambio de la Constitución en determinados contenidos, el Constituyente español ha buscado un rodeo para impedir de facto tal cambio» (p. 190). Sin embargo, en PÉREZ ROYO, J., «Una asignatura pendiente...», ob. cit., p. 216, reconoce que la Constitución española es «razonablemente rígida».

156 TAJADURA TEJADA, J., «La reforma de la Constitución (arts. 166-169)», en FREIXES SANJUÁN, T. y GAVARA DE CARA, J.C. (coords.), Repensar la constitución. Ideas para una reforma de la Constitución de 1978: reforma y comunicación dialógica. Parte primera, CEPC-BOE, Madrid, 2016, pp. 257-280.

${ }_{157}$ En este sentido, vid. GARCÍA ROCA, J. (ed.), Pautas..., ob. cit., pp. 125 y ss.

158 En opinión de MUÑOZ MACHADO, S., Vieja..., ob. cit., p. 142, modificar el art. 168 vía 167 es «una argucia bastante ingenua, y un fraude constitucional»si se dirige a introducir un cambio total de la Constitución, o sustancial. De forma más ponderada GARCÍA-ESCUDERO MÁRQUEZ, P., El procedimiento..., ob. cit., p. 134, afirma sobre si cabe reformar el art. 168 vía 167: "Dos argumentos contrapuestos creemos que han de sopesarse para tratar de llegar a una conclusión sobre el asunto. En primer lugar, la no referencia al artículo 168 entre las materias por él 
pesar de que su propia reforma no se incluya dentro de las materias para las que éste está previsto constitucionalmente.

\section{DUDAS SOBRE LA VIABILIDAD DE LA REFORMA CONSTITUCIONAL RECONDUCIDAS A UNA SUSPICACIA FINAL: LA ACTITUD (QUIZÁ APTITUD) POLÍTICA}

A estas alturas de la exposición puede convenirse que se ha salvado la primera de las objeciones ante una reforma constitucional: se han constatado "exigencias políticas» que conviene reconducir vía reforma constitucional y existen suficientes aportaciones técnicas que orientan la misma. Sin embargo, permanecen dudas sobre la viabilidad política, con el agravante de que en cierto modo, más que factores coyunturales, en nuestro país se usan para justificar que nunca llegue ese momento.

El primero de estos factores que se aduce para eludir la reforma de la Constitución es la rigidez de su procedimiento. Frente a esta excusa creo que deben considerarse dos cuestiones. La primera de ellas es que, como sabemos, para reformar la Constitución hay dos procedimientos, de los cuales el previsto en el artículo 167 que, según se ha visto, permitiría revisar la mayor parte de aspectos que hoy por hoy reclaman cambios, presenta como único elemento de rigidez la exigencia de mayorías cualificadas y, en su caso, la celebración de un referéndum. Un procedimiento que, cuando ha habido acuerdo político, ha permitido reformar la Constitución en quince días. Es cierto, eso sí, que atendiendo a las actuales mayorías parlamentarias lo más probable es que hoy día cualquier reforma pasara por la celebración de un referéndum, a diferencia de lo que ocurrió con las modificaciones de 1992 y de 2011. Pero tampoco ello debe considerarse como un óbice inasumible políticamente - al contrario-. En segundo lugar, aun cuando se quisiera acometer una reforma vía $168 \mathrm{CE}$, por mucho que éste es un procedimiento notablemente rígido (dos legislaturas sucesivas, mayorías muy cualificadas y referéndum necesario), no lo es más que el que tienen otras cons-

\footnotetext{
enumeradas como dotadas de especial rigidez permitiría entenderlo excluido de su ámbito, y en consecuencia reformable por vía del artículo 167; pero, de otra parte, no deja de latir en el fondo de tal razonamiento la impresión difusa de que se estaría yendo contra la voluntad del constituyente, por no emplear la expresión más fuerte de fraude a la Constitución. / Tal vez el conflicto entre ambos argumentos deba resolverse, si se utiliza un criterio literalista y formal, estrictamente jurídico, en favor del primero; sólo si se añaden ingredientes de índole metajurídica, caería el peso de la balanza hacia el segundo criterio».
} 
tituciones de países de nuestro entorno ${ }^{159}$. Por lo tanto, no es cierto que jurídicamente estemos ante un procedimiento intransitable. Nuevamente, si hay voluntad política, puede andarse ese camino. Como nos enseñaron los clásicos, la mayor o menor rigidez de una constitución afecta en poco a que se reforme mucho o poco ${ }^{160}$. Al final son factores culturales, históricos y políticos los que convierten a nuestro sistema en especialmente rígido, refractario a cualquier reforma constitucional. Lo que no nos exime de responsabilidad, como diremos a continuación, ya que precisamente la cultura democrática de un país se demuestra también siendo capaz de forjar consensos que permitan revisar sus pactos fundamentales ${ }^{161}$.

En puesto de ello, en nuestro país se ha generado la (falsa) confianza, más bien «tentación» de pensar que se puede mantener el actual marco constitucional sin revisiones formales, adaptándolo a los nuevos tiempos merced a una interpretación flexible ${ }^{162}$. En este sentido, como se ha dicho anteriormente, la Constitución no impone unos vínculos insalvables que hagan imprescindible su reforma e incluso muchas de sus obsolescencias pueden suplirse por vía legislativa y jurisprudencial. Por ello, dentro del respeto a la Constitución bienvenidas sean las actualizaciones que puedan desarrollarse. El problema es que no ha sido eso lo que ha ocurrido y, tal y como hemos visto, en los últimos tiempos las tensiones políticas y las flagrantes rupturas de la Constitución han puesto al Tribunal Constitucional en una situación difícilmente sostenible como garante de la supremacía constitucional. De forma que también debemos descartar esa confianza como justificación de la negativa a afrontar la reforma constitucional.

159 Así se reconoce también en AA.VV., Ideas para la reforma de la Constitución.

160 Así, WHEARE, K.C., Las constituciones modernas, ob. cit., p. 22; y el propio BRYCE, J., Constituciones flexibles y constituciones rígidas, CEPC, Madrid, 2015, p. 38.

${ }_{161}$ En este sentido BON, P., «La Constitución española en el marco del constitucionalismo contemporáneo», Revista Española de Derecho Constitucional, n. 69, 2003 , p. 21, destaca que en España la Constitución permanezca inmutable cuando actualmente se impone que las constituciones modernas se modifiquen frecuentemente, sin que ello signifique alterar los principios fundamentales del Estado.

${ }^{162}$ Sobre el riesgo de no reformar la Constitución y a cambio reformar las leyes, vid. GARCÍA ROCA, J., «De la revisión de las constituciones...», ob. cit., pp. 200 y ss. Muy expresivo resultaba en este punto DE VEGA, P., ob. cit., p. 93: «No acudir al procedimiento de reforma cuando las exigencias históricas, sociales y políticas así lo requieren, lejos de constituir una actividad de defensa del ordenamiento constitucional, lo que representa realmente es la creación de un divorcio entre realidad jurídico-constitucional y realidad política, con la consiguiente pérdida de prestigio y de capacidad normativizadora concreta del ordenamiento constitucional.». Aparecerán entonces «procedimientos subrepticios», condenables, a través de los que operarán los cambios. 
Lo que queda, en definitiva, son unas excusas políticas que, a mi juicio, tampoco son «disculpantes» ${ }^{163}$ : se dice que hay una «falta» de clamor popular a favor de la reforma y que no existe un consenso político para acometerla, o que se podría quebrar el «frágil» consenso constitucional. Se llega a recurrir a la máxima ignaciana que afirma «En tiempos de tribulación no hacer mudanzas», de forma que, amparándose en que vivimos (o estamos saliendo de) una situación de crisis económica y una grave quiebra política precisamente en relación con el modelo territorial, se evita pensar en reformas constitucionales. Pues bien, vaya por delante que no se dan ninguna de las circunstancias previstas por la Constitución que impiden iniciar su reforma (estados de alarma, excepción y sitio); pero es que, además, la reforma constitucional podría dar la oportunidad para enterrar el «hacha de guerra» y sentarse a dialogar con serenidad en este momento de crisis política. Asimismo, aducir falta de clamor popular supone una «necedad», como explica Rubio Llorente, ya que ni son manifestaciones populares las que reforman las constituciones ni es cierto que no hayan reivindicaciones políticas en este sentido cuando la mayoría de los partidos incluyen propuestas de reforma en sus programas electorales ${ }^{164}$. Como necio también es invocar la falta de consenso inicial, cuando éste ha de ser el resultado de un diálogo sincero ${ }^{165}$. Por último, el miedo a que algún partido pueda pretender romper la baraja e impugnar los pilares de convivencia tampoco ha de paralizar, porque precisamente esa parálisis puede terminar generando un riesgo todavía mayor para la vigencia de la Constitución ${ }^{166}$. Además, si es cierto que el consenso constitucional

163 Claramente lo ha expresado GARRORENA MORALES, A., "Nuevas condiciones...», ob. cit., p. 55, para quien, ante la falta de un contexto político favorable a la reforma, "[l]a conclusión que de ahí habría que deducir no tendría que ser la de que esa clase política queda, en consecuencia, exonerada de toda responsabilidad sino, antes bien, la de que la misma está incumpliendo con ello la grave responsabilidad que le incumbe respecto de la normalidad constitucional del Estado. Si las condiciones para la reforma no se dan, tarea prioritaria de todos debería ser el crearlas, renunciando - como a se hizo en los años setenta - a la inflexibilidad de unas premisas innegociables o a sustituir la reforma por atajos».

164 RUBIO LLORENTE, F., «La titularidad del derecho a la autonomía..., ob. cit.

165 Cfr. GARCÍA ROCA, J. (ed.), Pautas..., ob. cit., p. 22.

166 Como explicara BRYCE, J., ob. cit., pp. 88-89, existen dos tendencias opuestas que obran constantemente en los países regidos por constituciones rígidas, una de las cuales tiende a reforzarlas y la otra a debilitarlas: la primera sería el aumento del respeto por la Constitución que trae consigo los años; pero, la segunda, sería que el tiempo trabaja contra ella porque al cambiar las condiciones materiales y sociales del pueblo hacen que la Constitución no expresa de manera adecuada las necesidades políticas. Y frente a ello la salida ha de ser la reforma. 
se fraguó en un momento muy determinado de nuestra historia ${ }^{167}$, también lo es que ha tenido tiempo para asentarse.

De manera que parecen disiparse los factores que podrían generar alguna duda sobre la conveniencia de iniciar una reforma constitucional en nuestro país y lo único que permanece es una suspicacia: la falta de actitud (quizá también de aptitud) política para desarrollar la reforma constitucional. Tal y como reconocía Fernando Rey, lo que falta de verdad es «concordia» ${ }^{168}$, determinación política para sentarse y ser capaz de generar un espacio de diálogo político (no jurídico, porque ese ya existe en los artículos 167 y 168 de la Constitución) en el que forjar las mayorías cualificadas necesarias para atender a los acuciantes problemas que reclaman la reforma de nuestra Constitución ${ }^{169}$.

\section{A MODO DE CIERRE: LA REFORMA CONSTITUCIONAL, SI ES PRUDENTE Y SERENA, COMO ANTÍDOTO FRENTE AL ENVEJECIMIENTO DE LA CONSTITUCIÓN DE 1978}

Escribía J. Bryce que hay que llevar mucho cuidado con no poner sobre las constituciones rígidas más peso del que pueden aguantar, ya que están construidas "como un puente de hierro de ferrocarril, hecho sólidamente para resistir la más grande presión del viento o del agua que probablemente caerán sobre él. Si los materiales son sólidos y la hechura buena, el puente resiste con aparente facilidad y quizá sin mostrar signos de esfuerzo o movimiento, en tanto la presión quede dentro del límite previsto. Pero cuando este límite es rebasado, puede romperse en pedazos de repente y completamente» ${ }^{170}$.

La reforma de la Constitución se muestra así como una exigencia democrática que ayuda a aliviar ese peso ${ }^{171}$, precisamente porque

167 En este sentido DÍAZ REVORIO, F.J., «Perspectivas de la reforma...», pp. 15 y ss.

168 REY, F., ob. cit.

169 Tal y como señala GARCÍA ROCA, J., «De la revisión de las constituciones...», ob. cit., p. 206, la reforma depende no tanto de la rigidez formal sino de la viabilidad de un compromiso constituyente entre fuerzas políticas antagónicas; hallando el problema central en la falta de capacidad de una mayoría parlamentaria de encontrar aliados para aprobar una reforma constitucional.

170 BRYCE, J., ob. cit., p. 87.

171 Sobre la permanente tensión entre constitucionalismo y democracia que marca las dos grandes cuestiones de la Teoría de la Constitución (inmutabilidad y normatividad), véase RUBIO LLORENTE, F., «Rigidez...», ob. cit., p. 20 y DE VEGA, P., ob. cit., p. 57. Porque, como de forma sintética defiende GARCÍA ROCA, J., «De la revisión de las constituciones...», ob. cit., p. 200: «Sin revisiones periódicas, la idea de 
"prolonga la función constitucional de integración política» ${ }^{172}$ previniendo su envejecimiento y conjurando el riesgo de devenir obsoleta y terminar quebrando ${ }^{173}$. Un riesgo muy presente en España, no sólo en nuestra historia sino en nuestro presente. La insurgencia secesionista en Cataluña en pleno siglo XXI es el mejor ejemplo de ello.

Pero no el único. A lo largo de este trabajo hemos podido identificar diferentes factores que muestran por qué abrir un proceso de reforma de nuestra Constitución es la mejor vía para canalizar y aliviar las tensiones socio-políticas que hoy vive nuestro país.

Eso sí, no vale cualquier reforma; habrá de ser, según lo dicho, una reforma que se realice con prudencia y serenidad. Una reforma constitucional de Estado, pero no de estados ni de partidos, que preserve la condición de la Constitución de 1978 como "patrimonio común» ${ }^{174}$. Para ello, y con independencia de que se tramite en un acto único o en sucesivos, debe plantearse como una reforma de marcado carácter parlamentario, forjada por los representantes políticos de los españoles (a diferencia de la reforma impulsada por el Presidente Rodríguez Zapatero o, recientemente en Italia, por Renzi). Y en ella el consenso se ha de proyectar tanto en el procedimiento como en el contenido de la propia reforma. En primer lugar, técnicamente el consenso es un dato que se traduce en la exigencia de mayorías muy cualificadas, aunque no unanimidad, para la reforma de la Constitución. Pero, además, el procedimiento parlamentario debe estructurarse para hacer posible estas mayorías, ese consenso, no sólo político sino también social. Primero, delimitando el perímetro de la reforma ${ }^{175}$, y luego a través de procedimientos parlamentarios han de ser «deliberativos pero accesibles» ${ }^{176}$. Además, ha-

eficacia de una constitución normativa, desprovista de un periodo de vigencia o caducidad, es imposible. Ninguna norma legal dura eternamente. Sin reformas, la legitimidad democrática de la constitución como pacto fundador mengua sensiblemente. Precisamente por eso, el inmovilismo, el mero legalismo provisto de consideraciones de legitimidad, no es una actitud propia de un constitucionalismo democrático».

${ }_{172}$ GARCÍA ROCA, J., «De la revisión de las constituciones...», ob. cit., p. 207.

173 GARCÍA ROCA, J., «De la revisión de las constituciones...», ob. cit., p. 215216.

174 CARRERAS SERRA, F., «Conveniencia...», ob. cit.

175 Sobre la importancia de empezar la reforma de la Constitución delimitando adecuadamente una propuesta de iniciativa como fase previa, cfr. BELDA PÉREZPEDRERO, E., «El horizonte de la reforma constitucionl en España: no fue el momento adecuado», en VERA SANTOS, J.M. y DÍAZ REVORIO, F.J. (coords.), La reforma estatutaria y constitucional, La Ley, Madrid, 2009, pp. 553-585.

176 GARCÍA ROCA, J., "De la revisión de las constituciones...», ob. cit., pp. 188. Por ello, para abrir la reforma a la sociedad y dar participación ciudadana sería conveniente maximizar las posibilidades que ofrecen los reglamentos de las Cámaras (pienso, por ejemplo, en comparecencias de expertos, de Presidentes autonómicos...). 
brá de ser una reforma suscrita popularmente en referéndum. En un contexto de crisis como el actual, por muchas cautelas que pueda suscitar ${ }^{177}$, precisamente la exigencia de reenganchar a las generaciones más jóvenes reclama darles participación directa en la reforma de nuestra Norma fundamental. «Nunca máis» una reforma constitucional como la del $135^{178}$. Por último, el consenso se proyecta también sobre el propio contenido de la reforma. Algo que nos obliga a asumir que la Constitución ideal, aquella Constitución perfecta con la que cada uno de nosotros podemos soñar ${ }^{179}$, resulta imposible o indeseable. En la medida que la Constitución debe acoger bajo su techo a una pluralidad de visiones exige transacciones que nos alejan del ideal individual. Al final, su grandeza no viene dada por la perfección como texto normativo, sino por su «conciencia moral profunda» la cual reside, como expresaban nuestros Padres constitucionales, en «la voluntad de concordia, el propósito de transacción entre las posiciones encontradas y la búsqueda de espacios de encuentro señoreados por la tolerancia» ${ }^{180}$.

De forma que sólo si se asumen éstas premisas, a través de un procedimiento de concertación política y social, se puede aspirar a una reforma de la Constitución que sirva de antídoto contra el envejecimiento de nuestra Norma Fundamental, introduciendo las mejoras técnicas propuestas, $\mathrm{y}$, sobre todo, que renueve su legitimidad. Así, la reforma constitucional se concibe ante todo como una ocasión para la concordia política y la integración social en un momento de grave quiebra política y cambios sociales. Algo que, a pesar de la viveza del debate y de las iniciativas políticas que se han señalado, me sigue pareciendo lejano, probablemente por la suspicacia manifestada sobre la aptitud y las actitudes políticas. A mayor razón, cualquier intento de reformar la Constitución actualmente se tendrá que enfrentar a partidos políticos francamente desleales cuyo objetivo no es otro que el de derrocar el régimen del 1978, populismos y nacionalismos se dan la mano en esta empresa rupturista.

177 Sobre el referéndum constitucional y sus problemas, vid. DE VEGA, P., ob. cit., pp. 99 y ss.; GARCÍA ROCA, J., «De la revisión de las constituciones...», ob. cit., pp. 193 y ss.

178 Como expresa LÓPEZ AGUILAR, J.F., ob. cit., p. 213, «la reforma del 135 es un contraejemplo de cómo no hay que reformar una Constitución».

179 DE CARRERAS SERRA, F., "Conveniencia...», ob. cit., se refiere a cómo el consenso constitucional nos obliga a rechazar la constitución ideal que cada uno tiene en su cabeza.

180 Declaración de Gredos aprobada por los ponentes de la Constitución el 7 de octubre de 2003. Texto accesible en: http://www.abc.es/hemeroteca/ historico-08-10-2003/abc/Nacional/texto-integro-de-la-declaracion-de-gredosaprobada-ayer-por-los-ponentes-de-la-constitucion_212367.html 
Éste es el gran desafío al que todos nos enfrentamos. Porque la reforma de la Constitución sólo será posible si los políticos son capaces de generar amplios acuerdos, pero es la propia sociedad la que ha de repudiar los proyectos rupturistas y la política de crispación.

Es por ello que hemos de ser conscientes de que la reforma de la Constitución no es el bálsamo de Fierabrás para todos los males de nuestra sociedad. Probablemente, más que preguntarnos en qué falla la Constitución a lo mejor deberíamos cuestionar en qué le estamos nosotros fallando a la Constitución ${ }^{181}$. Indagar en qué medida hemos dejado que la Constitución moldee nuestro carácter nacional, como decía Bryce ${ }^{182}$. De ahí que, con Adela Cortina, concluya asumiendo que hoy por hoy nuestra prioridad es precisamente cultivar los valores constitucionales en nuestra sociedad ${ }^{183}$. Sólo así será posible superar en el siglo XXI esta asignatura pendiente de nuestra democracia.

\section{BIBLIOGRAFÍA}

AA.VV., La reforma del Senado, CEPC-Senado, Madrid, 1994.

AA.VV., «Encuesta», Teoría y Realidad Constitucional, n. 29, 2012, pp. 11-88.

AA.VV., «Reformas del federalismo alemán», Revista de Derecho constitucional europeo, n. 6, 2006, pp. 11-251.

AA.VV., El Senado, Cámara de representación territorial, Tecnos, Madrid, 1996.

AA.VV., Ideas para una reforma de la Constitución, 2017.

AA.VV., Ideas para una reforma de la Constitución, noviembre de 2017.

Aja Fernández, E., "Conferencia sobre la reforma de la Constitución», Instituto de Derecho Público. Texto accesible en: http:// idpbarcelona.net/docs/public/wp/nota_actualidad2.pdf

AJA FeRnÁndez, E., «La encrucijada constitucional», Claves de razón práctica, n. 241, 2015, pp. 18-27.

${ }^{181}$ En estos términos se desarrolló un interesante debate entre los profesores García Costa y González García con ocasión de un seminario sobre la situación en Cataluña impartido en la Universidad de Murcia por el profesor Enric Fossas el 14 de diciembre de 2017.

182 BRYCE, J., ob. cit., p. 4.

${ }^{183}$ CORTINA. A., "¿Es urgente reformar la Constitución?», El País, 12/12/2017.

(C) UNED. Revista de Derecho UNED, núm. 23, 2018 
AlCARAZ, H., «La organización territorial francesa en 2015: ¿Hacia una redefinición territorial», Cuadernos Manuel Giménez Abad, n. 10, 2015, pp. 22-35.

Álvarez Conde, E. (dir.), Reflexiones y propuestas sobre la reforma de la Constitución española, Comares, Granada, 2017.

Álvarez Conde, E., «Reflexiones sobre los actuales procesos de reforma constitucional y estatutaria», en AA.VV., Estudios sobre la Constitución española. Homenaje al Profesor Jordi Solé Turá, Cortes Generales, Madrid, 2008, pp. 1503-1522.

Aragón Reyes, M., Estudios de Derecho Constitucional, CEPC, Madrid, 2013, pp. 699 y ss.

ARroyo GIL, A., «¿El orden federal alemán como modelo para el futuro del Estado autonómico español?», en AA.VV., La Constitución política de España, CEPC, Madrid, 2016, pp. 373-399.

Arroyo Gil, A., «El federalismo alemán», en Tajadura, J. y De Miguel BÁrCENA, J. (eds.), Federalismos del siglo XXI, CEPC, Madrid, 2014, pp. 203-264.

ARRoYo GIL, A., «La reforma constitucional de 2009 de las relaciones financieras entre la Federación y los länder en la República Federal de Alemania», REAF, n. 10, 2010, p. 40-71.

ARRoyo GIL, A., La reforma constitucional del federalismo alemán, Generalidad de Cataluña. Instituto de Estudios Autonómicos, Barcelona, 2009.

AzPITARTE SÁnchez, M., «Tribunal Constitucional: necesidad y posible reforma», en FreIXES SANJUÁN, T. y GaVARA DE CARA, J.C. (coords.), Repensar la constitución. Ideas para una reforma de la Constitución de 1978: reforma y comunicación dialógica. Parte primera, CEPCBOE, Madrid, 2016, pp. 191-208.

Balaguer CALlejón, F., «La integración del pluralismo territorial infraestatal en los procesos normativos de la Unión Europea», en AA.VV., La Constitución política de España, CEPC, Madrid, 2016, pp. 401 y ss.

Ballester CARdell, M., «Reforma constitucional y poder judicial: dos propuestas para el caso español», en Ruiz-Rico RuIz, G. et al. (coords.), Regeneración democrática y reforma constitucional, Tirant lo Blanch, Valencia, 2017, pp. 53-88.

Belda PÉrez-Pedrero, E., «El horizonte de la reforma constitucionl en España: no fue el momento adecuado», en Vera SANTOS, J.M. y DÍAz REVORIO, F.J. (coords.), La reforma estatutaria y constitucional, La Ley, Madrid, 2009, pp. 553-585. 
Belda Pérez-Pedrero, E., La fallida reforma de la Constitución española durante la VIII Legislatura (2004-2008), Thomson Civitas, Navarra, 2008.

Bescansa, C., Ideas para el debate: Tres propuestas de cambio constitucional para hacer frente a la crisis territorial, 21/11/2017.

Biglino Campos, P., «El control de cuentas: un contenido necesario de la reforma constitucional», en FREIXES SANJUÁN, T. y GAVARA DE CARA, J.C. (coords.), Repensar la constitución. Ideas para una reforma de la Constitución de 1978: reforma y comunicación dialógica. Parte primera, CEPC-BOE, Madrid, 2016, pp. 151-172.

Bilbao UbiLlos, J.M., «La modificación del mapa autonómico: creación de nuevas Comunidades autónomas y alteración de los límites territoriales existentes», en AA.VV., Estudios sobre la Constitución española. Homenaje al Profesor Jordi Solé Turá, Cortes Generales, Madrid, 2008, pp. 1563-1597.

BlaIRon, K., "Organización territorial en Francia: alcance de las reformas de 2010», Revista catalana de dret públic, n. 43, 2011, pp. $343-371$

Blanco ValdÉs, R., «¿Por qué la federalización de España no ha colmado la reivindicación nacionalista?» en AA.VV., La Constitución política de España, CEPC, Madrid, 2016, pp. 417-438.

Blanco ValdÉs, R., El laberinto territorial español: del cantón de Cartagena al secesionismo catalán, Alianza, Madrid, 2014.

Blanco Valdés, R., Los rostros del federalismo, Alianza, Madrid, 2012.

Bon, P., "La Constitución española en el marco del constitucionalismo contemporáneo», Revista Española de Derecho Constitucional, n. 69, 2003.

BRYCE, J., Constituciones flexibles y constituciones rígidas, CEPC, Madrid, 2015.

C. Schмiтt, Teoría de la Constitución, Alianza, Madrid, 1982.

CABELlos EsPiÉRREZ, M.A., «Evolución y características actuales del federalismo alemán», en SolozÁBAl EchevarRía, J.J. (ed.), La reforma federal. España y sus siete espejos, Biblioteca Nueva, Madrid, 2014, pp. 159-202.

CONSEJO DE ESTADO: Informe sobre las propuestas de modificación del régimen electoral general, 24 de febrero de 2009. Texto accesible en: http://www.consejo-estado.es/pdf/regimen-electoral.pdf 
CONSEJO DE ESTADO: Informe sobre modificaciones de la Constitución española, 16 de febrero de 2006. Texto accesible en: http://www. consejo-estado.es/pdf/modificaciones\%20constitucion\%20esp.pdf

CORDERo GonZÁLEZ, E.M., «La reforma de la constitución financiera alemana. En particular, el nuevo límite al endeudamiento de la Federación y los Länder», Teoría y Realidad Constitucional, n. 29, 2012, pp. 289-234.

Cortina. A., "¿Es urgente reformar la Constitución?», El País, 12/12/2017. Texto accesible en: https://elpais.com/ elpais/2017/12/08/opinion/1512748526_051506.html

Dau-Lin, H., Mutación de la Constitución, IVAP, Oñate, 1999.

De Carreras Serra, F., "Conveniencia y necesidad de una reforma constitucional», Claves de razón práctica, n. 241, 2015, pp. 38-47

De Carreras Serra, F., «Reformar la Constitución para estabilizar el modelo territorial», en AA.VV., La reforma constitucional: ¿hacia un nuevo pacto constituyente?, CEPC, Madrid, 2009, pp. 47-112.

De Carreras Serra, F., "Una posible reforma constitucional del sistema de distribución de competencias», en AA.VV., La Constitución política de España, CEPC, Madrid, 2016, pp. 457-476.

De Vega, P., La reforma constitucional y la problemática del poder constituyente, Tecnos, Madrid, 1985.

Díaz Revorio, F.J., "Consideraciones sobre la reforma de la Constitución española desde la teoría de la Constitución», en VERA SANTOS, J.M. y DíAz REVORIO, F.J. (coords.), La reforma estatutaria y constitucional, La Ley, Madrid, 2009, pp. 587-532.

Díaz Revorio, F.J., «Perspectivas de la reforma de la Constitución española», Parlamento y constitución, n. 8, 2004, pp. 11-37.

DiCEY, A.V., Introduction to the study of the Law of the Constitution, Mac Millan and Co. Londres, 1961.

FERNÁNDEZ RODRíGUEZ, T.-R., «Una reforma necesaria, pero limitada», $A B C, 3 / 12 / 2017$.

FERNÁNDEZ SEgado, F., «Reflexiones en torno a la reforma constitucional del Senado», Revista de Derecho Político, n. 42, 1996.

FERnández-Miranda CAMPOAMOR, A., "Sobre la forma de gobierno: ¿un exceso de racionalización?», en Gacía Roca, J. y Alberti, E. (coords.), Treinta años de Constitución, Tirant lo Blanch, Valencia, 2010, pp. 847-870. 
Freixes Sanjuán, T. y Gavara de Cara, J.C. (coords.), Repensar la constitución. Ideas para una reforma de la Constitución de 1978: reforma y comunicación dialógica. Parte primera, CEPC-BOE, Madrid, 2016.

Freixes Sanjuán, T. y Gavara de Cara, J.C. (coords.), Repensar la constitución. Ideas para una reforma de la Constitución de 1978: reforma y comunicación dialógica. Parte primera, CEPC-BOE, Madrid, 2016.

FreIXES, T., «Los derechos fundamentales: el enfoque multinivel», en FreiXes SANJUÁn, T. y GaVARA DE CARA, J.C. (coords.), Repensar la constitución. Ideas para una reforma de la Constitución de 1978: reforma y comunicación dialógica. Parte primera, CEPC-BOE, Madrid, 2016, pp. 23-38.

Gacía Roca, J. y Alberti, E. (coords.), Treinta años de Constitución, Tirant lo Blanch, Valencia, 2010.

GARCÍA FERNÁNDEZ, J., "Reformar constitucionales posibles y reformas constitucionales imposibles. Notas previas a la reforma de la Constitución», Teoría y Realidad Constitucional, n. 30, 2012, pp. 301-314.

García Gestoso, N., «El proceso de integración europea y la Constitución Española de 1978: reflexiones sobre la necesidad o conveniencia de reformar nuestra Constitución para adaptarla a la dinámica europea», en RouRA, S. y TAJADURA, J. (dirs.), La reforma constitucional. La organización territorial del Estado, la Unión Europea y la igualdad de género, Biblioteca Nueva, Madrid, 2005, pp. 401-478.

García MoRales, M.J., «Investigación y federalismo: la reforma de la Ley Fundamental de Bonn de 2014, ¿qué cambia?», Teoría y Realidad Constitucional, n. 28, 2016, pp. 305-338.

García Pelayo, M., "Derecho Constitucional Comparado» en Obras Completas, vol. I, CEPC, Madrid, 1991.

García Pelayo, M., «El proyecto constitucional y los "derechos históricos"», El País, 24/09/1978. Texto accesible en: https://elpais.com/ diario/1978/09/24/espana/275436006_850215.html

García Roca, J. (ed.), Pautas para una reforma constitucional, Aranzadi, Navarra, 2014.

García Roca, J., «De la revisión de las constituciones: constituciones nuevas y viejas», Teoría y Realidad Constitucional, n. 40, 2017, pp. 181-222. 
García-Atance, M.V., Reforma y permanencia constitucional, CEPC, Madrid, 2002.

García-Escudero Márquez, P. (2015), «Regeneración del Parlamento, transparencia y participación ciudadana», Teoría y Realidad Constitucional, n. 36, pp. 171-216.

García-Escudero Márquez, P., «Las Cortes Generales: nuevos roles y transformación de funciones», en FreIXES SANJUÁN, T. y GAVARA DE CARA, J.C. (coords.), Repensar la constitución. Ideas para una reforma de la Constitución de 1978: reforma y comunicación dialógica. Parte primera, CEPC-BOE, Madrid, 2016, pp. 101-130.

García-Escudero MÁRQuez, P., El procedimiento agravado de reforma de la Constitución de 1978, CEPC, Madrid, 2007.

Garrorena Morales, A., "Nuevas condiciones desde las que replantear el cometido de la doctrina respecto de la reforma del Senado", en Gacía RocA, J. y Alberti, E. (coords.), Treinta años de Constitución, Tirant lo Blanch, Valencia, 2010, pp. 39-58.

Garrorena Morales, A., «Una propuesta para la reforma constitucional del Senado», Revista de las Cortes Generales, n. 34, 1995.

Garrorena Morales, A., Derecho constitucional. Teoría de la Constitución y sistema de fuentes, CEPC, Madrid, 2014.

GarRoRena Morales, A., Escritos sobre la democracia. La democracia y la crisis de la democracia representativa, CEPC, Madrid, 2014.

GaVARA DE CARA, J.C., «Los derechos fundamentales: valoración y posibles modificaciones», en FreIXes SANJUÁn, T. y GaVARA DE CARA, J.C. (coords.), Repensar la constitución. Ideas para una reforma de la Constitución de 1978: reforma y comunicación dialógica. Parte primera, CEPC-BOE, Madrid, 2016, pp. 39-72.

GerPe LaNDín, M. y CABELlos EsPiÉRREz, M.A., «La configuración del poder judicial en la Constitución y su desarrollo posterior: algunos aspectos relevantes», en FreIXes SANJUÁn, T. y GaVARA DE CARA, J.C. (coords.), Repensar la constitución. Ideas para una reforma de la Constitución de 1978: reforma y comunicación dialógica. Parte primera, CEPC-BOE, Madrid, 2016, pp. 209-228.

Gómez SÁNCHEZ, Y., «La monarquía parlamentaria en la Constitución de 1978: valoración y propuestas de reforma constitucional», en FreiXes SANJuÁn, T. y Gavara de CARA, J.C. (coords.), Repensar la constitución. Ideas para una reforma de la Constitución de 1978: reforma y comunicación dialógica. Parte primera, CEPC-BOE, Madrid, 2016, pp. 73-100. 
GonZÁLEZ EnCINAR, J.J., «La Constitución y su reforma», Revista Espanola de Derecho Constitucional, n. 17, 1986, pp. 345-391.

HerRero dE MiÑón, M., Tres conferencias sobre la reforma constitucional, Tirant lo Blanch, Valencia, 2016.

JÁUREGUI, G., «Algunas reflexiones sobre la reforma del modelo territorial», en AA.VV., La reforma constitucional: ¿hacia un nuevo pacto constituyente?, CEPC, Madrid, 2009, pp. 113-144.

JELLINEK, G., Reforma y mutación de la Constitución, CEC, Madrid, 1991.

Jimena QuesadA, L., «La actualización de la Constitución Española ante la Carta de derechos fundamentales de la Unión Europea», en Roura, S. y TAJADURA, J. (dirs.), La reforma constitucional. La organización territorial del Estado, la Unión Europea y la igualdad de género, Biblioteca Nueva, Madrid, 2005, pp. 479-523.

Laband, P., Die Wandlungen der Deutschen Reichsverfassung, Dresden, Zahn u. Jaensch, 1895.

LóPez AguilaR, J.F., «De la Constitución «irreformable» a la reforma constitucional «exprés»», Teoría y Realidad Constitucional, n. 29, 2012, pp. 199-218.

LóPEZ GARRIDO, D., «Hacia un nuevo Senado: propuesta de reforma constitucional», Revista de las Cortes Generales, n. 33, 1994.

Lucas Verdú, P., Curso de Derecho Político, vol. II, Tecnos, Madrid, 1974.

MARTíN VIDA, M.A., «La reforma del federalismo alemán. Una visión general», Teoría y Realidad Constitucional, n. 18, 2006, pp. 337-350.

Montabes Pereira, J., «Algunas reflexiones sobre las posibilidades, límites y falacias de la reforma del sistema electoral español», en RUIZ-RIco RuIZ, G. et al. (coords.), Regeneración democrática y reforma constitucional, Tirant lo Blanch, Valencia, 2017, pp. 135-158.

Montilla Marcos, J.A., «La financiación autonómica en la reforma constitucional», en FreiXes SANJUÁn, T. y Gavara de CARA, J.C. (coords.), Repensar la constitución. Ideas para una reforma de la Constitución de 1978: reforma y comunicación dialógica. Parte primera, CEPC-BOE, Madrid, 2016, pp. 227-156.

Morales Arroyo, J.M., «La segunda cámara como elemento necesario en la arquitectura constitucional», en Freixes Sanjuán, T. y GAVARA DE CARA, J.C. (coords.), Repensar la constitución. Ideas para una reforma de la Constitución de 1978: reforma y comunicación dialógica. Parte primera, CEPC-BOE, Madrid, 2016, pp. 131-150. 
Muñoz Machado, S., Informe sobre España, Crítica, Barcelona, 2012.

Muñoz Machado, S., Vieja y nueva Constitución, Crítica, Barcelona, 2016.

Oliver Araujo, J., "Proyectos de reforma para un modelo territorial agotado», en RuIz-Rico RuIz, G. et al. (coords.), Regeneración democrática y reforma constitucional, Tirant lo Blanch, Valencia, 2017, pp. 267-304.

ORtega, L., Reforma constitucional y reforma estatutaria, ThomsonCivitas, Navarra, 2005.

Pajares Montolío, E., «Revisión y reformas del régimen electoral», en RuIz-Rico RuIz, G. et al. (coords.), Regeneración democrática y reforma constitucional, Tirant lo Blanch, Valencia, 2017, pp. 159-202.

PÉrez Royo, J., «La reforma del estado autonómico», en AA.VV., Estudios sobre la Constitución española. Homenaje al Profesor Jordi Solé Turá, Cortes Generales, Madrid, 2008, pp. 1757-1772.

Pérez Royo, J., «Una asignatura pendiente: la reforma de la Constitución», Revista Española de Derecho Constitucional, n. 69, 2003, pp. 215-235.

PÉRez Royo, J., La reforma constitucional inviable, Catarata, Madrid, 2015.

Pérez Royo, J., La reforma de la Constitución, Congreso de los Diputados, Madrid, 1987.

Porras Nadales, A., "Crisis de la democracia representativa y reformas electorales», en Ruiz-Rico Ruiz, G. et al. (coords.), Regeneración democrática y reforma constitucional, Tirant lo Blanch, Valencia, 2017, pp. 127-134.

REY, F., «Los enemigos de la Constitución», El País, 11/12/2017.

Roura Gómez, S., "La reforma constitucional del Senado en la VIII Legislatura», en RouRA, S. y TAJADURA, J. (dirs.), La reforma constitucional. La organización territorial del Estado, la Unión Europea y la igualdad de género, Biblioteca Nueva, Madrid, 2005, pp. 337-364.

ROURA, S. y TAJAdURA, J. (dirs.), La reforma constitucional. La organización territorial del Estado, la Unión Europea y la igualdad de género, Biblioteca Nueva, Madrid, 2005.

Rubio Llorente, F., "Defectos de forma», Revista Española de Derecho Constitucional, n. 100, 2014, pp. 133-165. 
Rubio LloRente, F., «La titularidad del derecho a la autonomía: nacionalidades y regiones», en AA.VV., Estudios sobre la Constitución española. Homenaje al Profesor Jordi Solé Turá, Cortes Generales, Madrid, 2008, pp. 1805-1814.

Rubio Llorente, F., «Proceso constituyente, clamor popular y otros desvaríos", Ahora, 16/12/2015.

Rubio Llorente, F., «Rigidez y apertura en la Constitución» en AA.VV., La reforma constitucional: ¿hacia un nuevo pacto constituyente?, CEPC, Madrid, 2009, pp. 17-40.

Rubio LloRente, F., «Rigidez y rigor mortis», Claves de razón práctica, n. 241, 2015, pp. 9-17.

RUIPÉREZ, J., «Estudio preliminar. Estática y dinámica constitucionales en la España de 1978. Especial referencia a la problemática de los límites a los cambios constitucionales», en RourA, S. y TAJADURA, J. (dirs.), La reforma constitucional. La organización territorial del Estado, la Unión Europea y la igualdad de género, Biblioteca Nueva, Madrid, 2005, pp. 19-280.

RuIz-Rico Ruiz, G. et al. (coords.), Regeneración democrática y reforma constitucional, Tirant lo Blanch, Valencia, 2017.

ScheIDER, H.-P., «El nuevo Estado federal alemán. La reforma del federalismo I y su implementación», Teoría y Realidad Constitucional, n. 34, 2014, pp. 99-128.

SEIJAS ViLladangos, M.E., «Federalismo resiliente: vanguardia y retaguardia de una nueva organización territorial del Estado español», en Ruiz-Rico Ruiz, G. et al. (coords.), Regeneración democrática y reforma constitucional, Tirant lo Blanch, Valencia, 2017, pp. 305344.

SolozÁbal EcheVARRÍA, J.J. (ed.), La reforma federal. España y sus siete espejos, Biblioteca Nueva, Madrid, 2014.

SOlOZÁBAL EchEVARRÍA, J.J., "Nuevas perspectivas sobre la reforma del Senado», en AA.VV., Estudios sobre la Constitución española. Homenaje al Profesor Jordi Solé Turá, Cortes Generales, Madrid, 2008, pp. 903 y ss.

SOlozÁbAl EcheVARRÍA, J.J., "Una propuesta de cambio federal», en ID, La reforma federal. España y sus siete espejos, Biblioteca Nueva, Madrid, 2014, pp. 19-68.

Tajadura Tejada, J., «El Pacto social como límite a la reforma del acto constitucional», en ROURA, S. y TAJADURA, J. (dirs.), La reforma 
constitucional. La organización territorial del Estado, la Unión Europea y la igualdad de género, Biblioteca Nueva, Madrid, 2005, pp. 365-400.

TAJAdura TeJADA, J., «La constitucionalización del mapa autonómico: una reforma necesaria pero insuficiente», en RouRA, S. y TAJADURA, J. (dirs.), La reforma constitucional. La organización territorial del Estado, la Unión Europea y la igualdad de género, Biblioteca Nueva, Madrid, 2005, pp. 281-336.

TAJAdura TejadA, J., «La reforma de la Constitución (arts. 166-169)», en Freixes Sanjuán, T. y Gavara de Cara, J.C. (coords.), Repensar la constitución. Ideas para una reforma de la Constitución de 1978: reforma y comunicación dialógica. Parte primera, CEPC-BOE, Madrid, 2016, pp. 257-280.

TAJAdura Tejada, J., «Las reformas del modelo de descentralización territorial de Francia: la necesaria simplificación del «milhojas territorial»», RVAP, n. 108, 2017, pp. 181-223.

Tajadura, J. y De Miguel Bárcena, J. (eds.), Federalismos del siglo XXI, CEPC, Madrid, 2014

Teruel Lozano, G.M., «El Tribunal Constitucional ante el principio de primacía del Derecho comunitario", Anales de Derecho. Universidad de Murcia, n. 24, 2006, pp. 319-352.

TERUel LozANo, G.M., «La reforma de los reglamentos parlamentarios como instrumento para la regeneración democrática», Revista administración \& ciudadanía, n. 1, 2017.

Torres Del Moral, A., "¿Reforma constitucional o reforma política?», en RuIz-Rico RuIz, G. et al. (coords.), Regeneración democrática y reforma constitucional, Tirant lo Blanch, Valencia, 2017, pp. 17-52.

Torres del Moral, A., «Estado autonómico, segunda fase», en Vera SANTOS, J.M. y Díaz ReVORIO, F.J. (coords.), La reforma estatutaria y constitucional, La Ley, Madrid, 2009, pp. 33-82.

Torres Muro, I., «Tribunal Constitucional: composición y funciones», en Freixes Sanjuán, T. y Gavara de CARA, J.C. (coords.), Repensar la constitución. Ideas para una reforma de la Constitución de 1978: reforma y comunicación dialógica. Parte primera, CEPCBOE, Madrid, 2016, pp. 173-190.

Vera SANTOS, J.M. y Díaz Revorio, F.J. (coords.), La reforma estatutaria y constitucional, La Ley, Madrid, 2009. 
Vera SANTOS, J.M., La reforma constitucional en España, La Ley, Madrid, 2007.

VesPaZiani, A., «El referéndum constitucional y la saga de las reformas institucionales en Italia: much ado about nothing», Revista de Derecho constitucional europeo, n. 27, 2017, pp. 1-20.

Wheare, K.C., Las constituciones modernas, Ed. Labor, Barcelona, 1971. 
